NASA Technical Memorandum 103765

AIAA - $91-0479$

$1 N-28$

11689

p.24

\title{
Mechanisms and Modeling of the Effects of Additives on the Nitrogen Oxides Emission
}

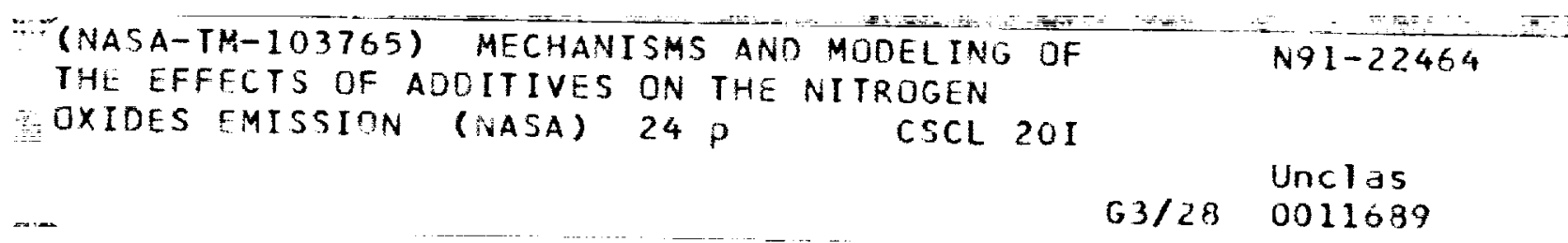

Krishna P. Kundu, H. Lee Nguyen, and M. Paul Kang Lewis Research Center

Cleveland, Ohio

Prepared for the

29th Aerospace Sciences Meeting

sponsored by the American Institute of Aeronautics and Astronautics

Reno, Nevada, January 7-10, 1991 


\author{
Krishna P. Kundu, * H. Lee Nguyen, and M. Paul Kang \\ National Aeronautics and Space Administration \\ Lewis Research Center \\ Cleveland, Ohio 44135
}

SUMMARY

A theoretical study on the formation of the oxides of nitrogen in the combustion of hydrocarbons is presented in this communication. Our current understanding of the mechanisms and the rate parameters for gas phase reactions have been used to calculate the NOx emission. The possible effects of different chemical species on thermal NOx, on a long time scale have been discussed. The mixing of these additives at various stages of combustion has been considered and NOx concentrations have been calculated; effects of temperatures have also been considered. The chemicals such as hydrocarbons, $\mathrm{H}_{2}, \mathrm{CH}_{3} \mathrm{OH}, \mathrm{NH}_{3}$ and other nitrogenous species have been chosen as additives in this discussion. Results of these calculations can be used to evaluate the effects of these additives on the NOx emission in the industrial combustion systems.

\title{
INTRODUCTION
}

The oxides of nitrogen play an important role in the photochemical processes that are responsible for the acid rain and smog formation (ref. 1). NOx is generated from nitrogen in air (ref. 2) and in the fuel (ref. 3) used in the combustion processes including the industrial boilers. Nitrogen and oxygen react at high temperature (ref. 4) to form NOx which has been described as thermal NOx while the fragments of hydrocarbons form the nitrogenous compounds which oxidize to prompt NOx (ref. 5). The three major types of nitrogen oxides are $\mathrm{NO}, \mathrm{NO}_{2}$ and $\mathrm{N}_{2} \mathrm{O}$, and it is well known that their distribution in the emission is dependent on temperature.

It is well known that very little NOx is produced if the combustion takes place in fuel-rich condition when oxygen mostly reacts with the fuel. but in oxygen rich condition, particularly near the stoichiometric condition of burning (ref. 6 ), temperature of combustion is very high and the thermal NOx formation is very rapid. In this study, all the NOX have been assumed to be thermal NOx and these are formed during combustion.

The thermal NOx formation can be partially controlled by the modification of the design of the combustor (ref. 7). These modifications reduce the flame temperature and thus retards the formation of NOx. Although this technique reduces the NOx formation, in some cases it is not enough and it is necessary to reduce NOx still further. Post-combustion treatment (refs. 1, 8 to 12) of the exhaust gas is one way to reduce NOx. Various exhaust treatment processes are in use for specific types of combustion devices. For example, in the exhaust of spark-ignited automotive engines, noble metal catalyst is used along with combustion stoichiometry to reduce NOx; other alternative concepts of NOx reductions have also been considered (refs. 8 and 12). The concept of using additives to the exhaust stream for reduction of NOX

\footnotetext{
*National Research Council - NASA Research Associate at Lewis Research Center.
} 
has become popular; the concept of converting NOx chemically to some form which can be comparatively easily removed by washing with water, has also been used (ref. 13).

The various technologies that have been developed so far for the postcombustion treatment can be carried out in either dry or wet systems. The dry method includes homogeneous (noncatalytic reduction), catalytic reduction, sorption by solids (physical adsorption or chemical absorption) and catalytic decomposition. Most process development efforts have concentrated on the selective reduction of NOx by adding ammonia (ref. 8) and other nitrogenous compounds (ref. 10) to the exhaust stream either with or without catalyst (ref. 11). $\mathrm{NH}_{3}$ in presence of other additives have also been considered to reduce NOx (ref. 14).

Wet methods for the removal of NOX are limited by the relatively inert nature of NO. This difficulty can be overcome by oxidation of $\mathrm{NO}$ to the more reactive $\mathrm{NO}_{2}$ in the gaseous phase. In this study we have considered the effects of $\mathrm{H}_{2}, \mathrm{CH}_{4}, \mathrm{C}_{2} \mathrm{H}_{6}$ and $\mathrm{CH}_{3} \mathrm{OH}$ as possible additives to oxidize $\mathrm{NO}$. Calculation results indicate that these methods are superior to the conventional oxidation methods (ref. 1).

This study has involved only modeling to estimate the potential of using additives to control NOx. Modeling can be considered as a reliable predictive tool within certain limit due in large part to the recent advances in the computer calculations and to the availability of detailed chemical kinetics models of hydrocarbons and nitrogen containing molecules.

\section{Physical/Computation Models and Kinetic Mechanisms}

In the present study, we are focussing on the use of additives to the control of NOX. The formation of NOX is dependent on temperature. At high temperature, particularly when the fuel-air ratio is close to 1, thermal NOx formation is very fast. Unless temperature is reduced, no additive is expected to reduce Nox so long both nitrogen and oxygen are present. So if the NOx has to be reduced in such condition, the exhaust emission has to be cooled before any additive is added. Since the objective of this study is to evaluate the effect of additives on the oxides of nitrogen, the exhaust emission was cooled to arbitrary temperature before the additives were added. It is however, necessary to know the concentrations of different species present in the emission in order to do the calculations. It may be assumed that the combustion is complete within a fraction of the second and therefore the composition of the emission in most cases have been assumed to be equivalent to the equilibrium composition. Figures $1(a)$ and (b) show that equilibrium compositions in the combustion of methane depend on various factors including the initial fuel and air temperatures. Since the objective of this report is to evaluate the effects of additives on the NOx emission, we have arbitrarily chosen a concentration of NO in combination with 4.2 percent oxygen and 10 percent water. We have also assumed that practically all the NOx in the equilibrium mixture is in the form of NO and no N02 is present. This assumption is justified because at higher temperature N02 is converted into NO.

We have also considered the effects of various additives in presence of hydrocarbon fragments. In order to do that, calculations were made using composition of the exhaust stream before the combustion was complete. In this case, the composition of the various species are different from the equilibrium composition. Application of modeling requires the knowledge of the concentrations of all these species including the radical species. We have therefore used a well stirred reactor model 
of the combustion of methane at 0.5 to 0.8 equivalent ratio and chosen the concentration of different species at about $2 \mathrm{msec}$ residence time. Lsens computer code developed by Bittker and Radhakrishnan (ref. 15) was used in these calculations. Plug flow reaction model of Lsens code was used to calculate the NOx concentrations after the additives were added. The thermodynamic data required in these calculations were obtained from the data set supplied with the Lsens code and also from Sandia report (ref. 16).

The chemical kinetic mechanism is essentially identical to that developed by Miller and Bowman (ref. 14); a few reaction species were however eliminated to make it fit to the Lsens code. This model was tested by actual comparison of the experimental data using WSR model of thermal NOx (ref. 17) formation in the combustion of methane at various fuel-air ratio. Few reactions of methanol and species derived from it as described by Westbrook and Dreyer (ref. 18), were included in this mechanisms; reactions $(220,221,222,223)$ involving hydrazine and its decomposition products were also included. Table I shows the reactions used in this mechanism. This mechanism includes chemical processes of methane combustion, formation of NO by Zeldovitch and prompt NOx mechanism (refs. 2 and 5) as well as the removal of nitric oxide.

\section{Combustor Exhaust Gas Modeling}

The primary objective of this study is to evaluate the effect of additives on NOx in presence or in absence of unburnt hydrocarbon fragments at various temperatures. In order to do that, emission products at arbitrary locations were chosen; these species were then cooled to different temperatures and the additives were added. Changes in NOx with time were calculated; calculations for a prolonged period were made in order to determine the usefulness of the particular additive. The calculation shows that the fragments of hydrocarbons have definite effects on the reactions involving NOx. Since the present study uses only methane as fuel, the amount of NOx produced may be much less than what is normally generated during burning of conventional fuels containing fuel-bound nitrogen. In our calculations we assumed that about 500 to $1000 \mathrm{ppm}$ NO were present in the emission; the similar level of NOX was assumed in the emission containing hydrocarbon fragments also.

Figures 1 and 2 shows the equilibrium concentrations of $\mathrm{NO}$ and $\mathrm{NO}_{2}$ at different fuel-air ratio. It appears that in the equilibrium condition NOx remains mostly in the form of NO. Table II shows the result of cooling the emission containing hydrocarbon fragments to different temperatures and following the reactions under constant temperature condition. It appears that at lower temperature there is a gradual growth of $\mathrm{NO}_{2}$, although total $\mathrm{NOx}$ is not affected. It also appears that $\mathrm{NO}_{2}$ concentration gradualiy falls with increase in temperature. This suggests that probably hydrocarbon fragments help in the oxidation of $\mathrm{NO}_{0}$ to $\mathrm{NO}_{2}$ and this oxidation seems to be more effective at lower temperature. Ito and Yano (ref. 22) showed in their studies on the combustion of methanol that the oxidation of methanol is catalyzed by NO. Later Lyon et al. (ref. 23) showed that methanol helps in the oxidation of $\mathrm{NO}$, and the oxidation takes place mostly by $\mathrm{HO}_{2}$. It appears that similar oxidation of NO takes place in presence of hydrocarbon fragments as well.

In the present study the oxidation of NO in presence of hydrocarbons and methanol will be discussed. The reduction of NO to nitrogen in presence of nitrogenous compounds will also be discussed. 
Oxidation of $\mathrm{NO}$ to $\mathrm{NO}_{2}$ Effect of Hydrogen, Hydrocarbons and Alcohols

It was mentioned before that probably $\mathrm{HO}_{2}$ is the major oxidizing agent in the oxidation of $\mathrm{NO}$. Since hydrogen can generate $\mathrm{HO}_{2}$, it may be assumed that hydrogen can oxidize NO. Figure $3(\mathrm{a})$ shows the effect of hydrogen on NO at various temperatures and figure $3(\mathrm{~b})$ shows similar effect when additional oxygen was added. It appears that oxidation of NO requires large amount of hydrogen and even then the oxidation to $\mathrm{NO}_{2}$ decreases with increase in temperature; moreover, additional oxygen does not help very much in the oxidation. At lower temperature a part of NO is oxidized to $\mathrm{NO}_{2}$, but as the temperature is increased $\mathrm{NO}_{2}$ changes back to NO. It is true that at high temperature $\mathrm{H}$ and $\mathrm{O}_{2}$ react to form both $\mathrm{HO}_{2}$ and $\mathrm{OH}$, and the rate of formation of $\mathrm{OH}$ is faster than the rate of formation of $\mathrm{HO}_{2} ;$ moreover, $\mathrm{HO}_{2}$ reacts with $\mathrm{OH}$. It therefore appears that $\mathrm{HO}_{2}$ does not get much chance to oxidize NO. These results suggest that hydrogen is not a good additive towards oxidation of NO.

The major reactions in the oxidation of $\mathrm{NO}$ in presence of $\mathrm{H}_{2}$ can be written as

$$
\begin{aligned}
& \text { formation of } \mathrm{HO}_{2} \ldots . \mathrm{H}+\mathrm{O}_{2} \ldots . \mathrm{HO}_{2}+\mathrm{M} \ldots \text { (127) } \\
& \text { formation of } \mathrm{OH}^{2} \ldots \ldots . \mathrm{H}+\mathrm{O}_{2} \ldots \ldots \mathrm{O}^{2}+\mathrm{OH} . .(125) \\
& \text { removal of } \mathrm{HO}_{2} \ldots \ldots . . \mathrm{HO}_{2}+\mathrm{NO} \ldots \ldots \mathrm{NO}_{2}+\mathrm{OH} . .(230)
\end{aligned}
$$

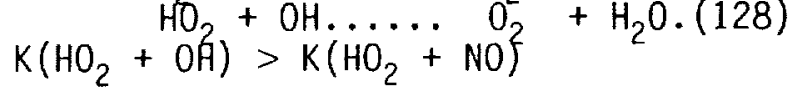

The study with hydrogen suggests that if we could use an additive that can generate $\mathrm{HO}_{2}$ and also can scavenge $\mathrm{OH}$, oxidation of $\mathrm{NO}$ would be more effective. Among the hydrocarbons methane is the simplest and it also generates $\mathrm{HO}_{2}$. Figures $4(b)$ and (a) show the effect of methane on NO with and without the presence of additional oxygen. It appears that the effect of methane is not different from what was observed with hydrogen. At lower temperature $\mathrm{No}$ oxidizes partly to $\mathrm{NO}_{2}$ and at higher temperature $\mathrm{NO}_{2}$ changes back to $\mathrm{NO}$. Although methane generates $\mathrm{HO}_{2}$, it is not a good scavenger of $\mathrm{OH}$.

$$
\begin{aligned}
& \text { formation of } \mathrm{HO}_{2} \ldots \mathrm{CH}_{4}+\mathrm{O}_{2} \ldots \mathrm{CH}_{3}+\mathrm{HO}_{2} \ldots \text { (3) } \\
& \mathrm{CH}_{3}+\mathrm{O}_{2} \ldots \mathrm{CH}_{3} \mathrm{O}+0 \ldots \\
& \mathrm{CH}_{3} \mathrm{O}+\mathrm{O}_{2} \ldots \mathrm{CH}_{2} \mathrm{O}+\mathrm{HO}_{2} \\
& \text { formation of } \mathrm{OH} \ldots . \mathrm{CH}_{4}+0 \ldots \mathrm{CH}_{3}+\mathrm{OH} \ldots \text { (6) } \\
& \text { removal of } \mathrm{HO}_{2} \ldots . . \mathrm{HO}_{2}+\mathrm{NO} \ldots \mathrm{NO}_{2}+\mathrm{OH} \ldots \text { (230) } \\
& \mathrm{HO}_{2}+\mathrm{OH} \ldots \mathrm{O}_{2}+\mathrm{H}_{2} \mathrm{O} \ldots \text { (128) } \\
& \text { removal of } \mathrm{OH}\left(\text { slow) } \mathrm{CH}_{4}+\mathrm{OH}_{\ldots} . \mathrm{CH}_{3}+\mathrm{H}_{2} \mathrm{O} \ldots\right. \text { (5) }
\end{aligned}
$$

Addition of additional oxygen increases the formation of $\mathrm{HO}_{2}$ but at the same time increases the rate of formation of $\mathrm{OH}_{\text {; }}$ the net result is that the NO oxidation does not improve.

Addition of large amount of methane makes the emission fuel rich; in such case at higher temperature total NOX is reduced as shown in figure 5. In this case as oxygen is not available, hydrocarbon fragments generate species like $\mathrm{CN}, \mathrm{HCN}$ or $\mathrm{C}_{2} \mathrm{~N}_{2}$ and these species react with NO. Figure 5 shows that at equivalent ratio $2.0 \mathrm{NOX}$ is actually reduced by methane at higher temperature. 
Figure 6(a) shows the effect on NOx at various temperature when ethane is added to the emission. In this case however, $\mathrm{NO}_{2}$ is found to increase as the temperature increases. At about $1075^{\circ} \mathrm{K}$, NO is almost completely changed to $\mathrm{NO}_{2}$. It should be mentioned here that as soon as all of ethane is consumed, $\mathrm{NO}_{2}$ changes back to $\mathrm{NO}$ and there is no more ethane present to regenerate $\mathrm{NO}_{2}$. According to the reactions assumed in the mechanism used in this study, ethane is a good scavenger for $\mathrm{OH}$ and the $\mathrm{OH}$ scavenging rate increases with increase in temperature. The major reactions taking place in this case can be written as

$$
\begin{aligned}
& \text { formation of } \mathrm{HO}_{2} \ldots \mathrm{C}_{2} \mathrm{H}_{6}+\mathrm{O}_{2} \ldots \mathrm{C}_{2} \mathrm{H}_{5}+\mathrm{HO}_{2} \\
& \mathrm{C}_{2} \mathrm{H}_{5}+\mathrm{O}_{2} \ldots \mathrm{C}_{2} \mathrm{H}_{4}+\mathrm{HO}_{2} \\
& \mathrm{C}_{2} \mathrm{H}_{4}+\mathrm{H}, 0,0 \mathrm{H} \ldots \ldots \mathrm{C}_{2} \mathrm{H}_{3} \quad(77,78,79) \\
& \mathrm{C}_{2} \mathrm{H}_{3}+\mathrm{O}_{2} \ldots \mathrm{C}_{2} \mathrm{H}_{2}+\mathrm{HO}_{2} \\
& \mathrm{C}_{2} \mathrm{H}_{2}+\mathrm{O}_{2} \ldots . \mathrm{HCO} \\
& \mathrm{HCO}+\mathrm{O}_{2} \ldots \mathrm{CO}_{2}+\mathrm{HO}_{2} \\
& \text { Consumption of } \mathrm{OH} \ldots \mathrm{C}_{2} \mathrm{H}_{6}+\mathrm{OH} \ldots \mathrm{C}_{2} \mathrm{H}_{5}+\mathrm{H}_{2} \mathrm{O}
\end{aligned}
$$

Therefore it appears that ethane is a good additive towards oxidation of NO. In fact as the length of the hydrocarbon chain increases, the oxidation of NO becomes more effective.

Calculations were also performed using methanol as additives. Figure 6(b) shows the effect of methanol on NO at various temperatures. The effect appears to be very similar to what was observed in case of ethane. The oxidation seems to be maximum around $1100^{\circ} \mathrm{K}$. It should be mentioned here that Lyon et al. actually observed this effect (ref. 23). As soon as methanol is consumed, the $\mathrm{NO}_{2}$ changes back to NO. The reactions taking place with ethane or methanol are similar. Methanol generates $\mathrm{HO}_{2}$ and also scavenges $\mathrm{OH}$.

$$
\begin{aligned}
& \mathrm{CH}_{3} \mathrm{OH}+\mathrm{O}_{2} \ldots \ldots \ldots \ldots \mathrm{CH}_{2} \mathrm{OH}+\mathrm{HO}_{2} \\
& \mathrm{CH}_{3} \mathrm{OH}+\mathrm{H}_{1} \mathrm{OH}, 0,02 \ldots \mathrm{CH}_{2} \mathrm{OH} \\
& \mathrm{CH}_{2} \mathrm{OH}+\mathrm{O}_{2} \ldots \ldots \ldots \ldots \mathrm{CH}_{2} \mathrm{O}+\mathrm{HO}_{2}
\end{aligned}
$$

It appears therefore that both ethane and methanol are good additives towards oxidation of NO. Table III shows a comparison of behaviors of different additives towards oxidation of $\mathrm{NO}$ to $\mathrm{NO}_{2}$.

\section{Reduction of $\mathrm{NO}$ to $\mathrm{N}_{2}$ Effect of Nitrogenous Compounds}

Calculations were performed for the cases of added $\mathrm{NH}_{3}$ and $\mathrm{N}_{2} \mathrm{H}_{4}$ to the exhaust emission with and without another additive. Effect of $\mathrm{NH}_{3}$ on $\mathrm{NOx}$ has been well studied. It is well known that $\mathrm{NH}_{3}$ reduces $\mathrm{NO}$ within a narrow temperature range. Figure 7 (a) shows the effect of ammonia addition to the exhaust stream at various temperatures. It was first pointed out by Fennimore (refs. 20 and 21) and 1ater supported by many workers (ref. 6) that $\mathrm{NH}_{2}$ is the most important species in the reduction of NO by ammonia. The reactions that take place can be described by the 
schematic diagram (fig. 8(a)) as was presented by Miller and Bowman (ref. 14). $\mathrm{NH}_{2}$ either reacts with $\mathrm{NO}$ or is oxidized by oxygen atom; the species $\mathrm{N}_{2} \mathrm{H}$ produced in the reaction of $\mathrm{NH}_{2}$ with $\mathrm{NO}$ reacts with $\mathrm{NH}_{2}$ or $\mathrm{NO}$ depending on their concentrations.

$$
\begin{array}{ccc}
\text { formation of } \mathrm{NH}_{2} & \mathrm{NH}_{3}+\mathrm{O}, \mathrm{H}, \mathrm{OH} \ldots \mathrm{NH}_{2} & (210,209,208) \\
\text { Reactions of } \mathrm{NH}_{2} & \mathrm{NH}_{2}+\mathrm{NO} \ldots \mathrm{N}_{2}+\mathrm{H}_{2} \mathrm{O} & (207) \\
& \mathrm{NH}_{2}+\mathrm{O} \ldots \mathrm{HNO}+\mathrm{H}
\end{array}
$$

At lower temperatures $\mathrm{NH}_{2}$ concentrations are low as the concentrations of the oxidizing radicals which can oxidize ammonia are low. As the temperature increases, $\mathrm{NH}_{2}$ concentrations increase and the NO disappears faster. Increase in temperature also leads to the formation of NO and therefore reduction of NO decreases with further increase in temperature. This mechanism nicely explains the temperature window effect in the reduction of NO in presence of ammonia. The maximum reduction of NO appears to take place around $1150^{\circ} \mathrm{K}$, and this agrees very well with the experimental results. Since the formation of $\mathrm{NH}_{2}$ is dependent on the concentration of 0 atom which is generated from oxygen, it is expected that $N 0$ reduction efficiency should depend on the oxygen concentration. The above reaction scheme also suggests that increase in ammonia concentration will favor the N0 reduction. Figures $8(b)$ and (c) show the effects of oxygen and ammonia concentrations on the reduction of No. It should be mentioned here that this kind of dependence was actually observed by Lyon (ref. 19).

The present mechanism indicates that $\mathrm{NH}_{2}$ is the most important species in the reduction of NO. That ammonia does not reduce NO at lower temperature, is probably due to the fact that $\mathrm{NH}_{2}$ is not generated sufficiently at lower temperature. So if the $\mathrm{NH}_{2}$ formation could be expedited, probably NO reduction would be possible at lower temperature. Figure $7(b)$ shows that in presence of hydrocarbon fragments, N0 reduction by ammonia takes place at lower temperature. Hydrocarbon fragments react with nitrogen and generate carbon-nitrogen compounds which react with NOx; at the same time hydrocarbon fragments burn to produce heat which help in the production of 0 atom, and 0 atoms react with ammonia to produce $\mathrm{NH}_{2}$. Lyon (ref. 24) observed that addition of hydrogen shifts the temperature window to the lower temperature side in the NO reduction by ammonia. Figures $9(a)$ and (b) show the effect of addition of hydrogen on the reduction of NO in presence for ammonia. Obviously, the higher the concentration of hydrogen, the greater is the shift of the window. The addition of hydrogen generates heat to promote the generation of $\mathrm{NH}_{2}$; moreover reduction of $\mathrm{NO}$ takes place by hydrogen atoms

$$
\begin{aligned}
& \mathrm{H}_{2}+\mathrm{O}_{2} \cdots \quad 2 \mathrm{OH} \\
& \mathrm{OH}+\mathrm{H}_{2} \cdots \mathrm{H}+\mathrm{H}_{2} \mathrm{O}
\end{aligned}
$$




$$
\begin{aligned}
& \mathrm{H}+\mathrm{O}_{2} \ldots \mathrm{O}+\mathrm{OH} \\
& \mathrm{O}+\mathrm{NH}_{3} \ldots \mathrm{NH}_{2}+\mathrm{OH} \\
& \mathrm{NH}_{3}+\mathrm{H}, \mathrm{OH} \ldots \mathrm{NH}_{2} \\
& \mathrm{NH}_{2}+\mathrm{NO} \ldots \mathrm{N}_{2}+\mathrm{H}_{2} \mathrm{O}
\end{aligned}
$$

Reduction of NO

$$
\text { ... } \mathrm{N}_{2} \mathrm{H}+\mathrm{OH}
$$

$$
\begin{aligned}
& \mathrm{H}+\mathrm{NO} \ldots \mathrm{N}+\mathrm{OH} \\
& \mathrm{N}+\mathrm{NO} \ldots \mathrm{N}_{2}+0
\end{aligned}
$$

Figure $9(\mathrm{a})$ shows that in presence of $500 \mathrm{ppm}$ hydrogen, maximum reduction of N0 by ammonia takes place at temperature below $1100^{\circ} \mathrm{K}$, and at $1000^{\circ} \mathrm{K}$ about 50 percent reduction of $N 0$ is possible. Figure $9(\mathrm{~b})$ shows that with $5000 \mathrm{ppm}$ of $\mathrm{H}_{2}$, NO reduction is practically complete at $950^{\circ} \mathrm{K}$. It appears that addition of $\mathrm{H}_{2}$ only shifts the temperature window without changing much of its width. With increase in temperature, N0 reduction efficiency gradually decreases.

Calculations were made to study the effects of methanol on the N0 reduction by ammonia. Figure $10(a)$ shows the effect of temperature on the No reduction by ammonia in presence of methanol. Here also as in the case of hydrogen, methanol generates heat and thus helps to produce $\mathrm{NH}_{2}$. Figure 10 (b) shows the reaction temperatures at around $5 \mathrm{sec}$ after the addition of alcohol-ammonia mixture. Addition of methanol at $975^{\circ} \mathrm{K}$, increases the reaction temperature to over $1100^{\circ} \mathrm{K}$. At lower temperature and at a shorter time however, methanol burning is incomplete and the temperature is lower; as a result, there is less amount of 0 atoms produced and therefore less amount of $\mathrm{NH}_{2}$ is generated. As time passes, more 0 atoms are produced and more $\mathrm{NH}_{2}$ is generated.

$$
\begin{array}{r}
\mathrm{NH}_{3}+0 \ldots \mathrm{NH}_{2}+\mathrm{OH} \\
\mathrm{NH}_{2}+\mathrm{NO} \ldots \mathrm{N}_{2}+\mathrm{H}_{2} \mathrm{O} \\
\ldots \mathrm{N}_{2} \mathrm{H}+\mathrm{OH} \\
\mathrm{NNH}+\mathrm{NO} \ldots \mathrm{N}_{2}+\mathrm{HNO}
\end{array}
$$

as temperature rises rate of formation of $\mathrm{NH}_{2}$ increases

$$
\text { also } M+N H O \ldots H+N O \text { is faster (217) }
$$

Again, methanol like hydrogen only shifts the temperature window without changing the width. This is because at higher initial temperature, the reaction temperature is higher and oxidation of $\mathrm{NH}_{2}$ by 0 atoms becomes faster. Figure 10 (b) shows a plot of the reaction temperature versus various initial temperature; it appears that addition of methanol actually raises the reaction temperature helping in the formation of $\mathrm{NH}_{2}$.

Table III shows a comparison of the effects of temperature on the addition of various fuels to the reduction of NO by ammonia. It thus appears that fuels help in the generation of $\mathrm{NH}_{2}$ at lower initial temperature. Besides fuels, addition of $\mathrm{H}_{2} \mathrm{O}_{2}$ also may help to generate $\mathrm{NH}_{2}$ at lower initial temperature. Figure 11 shows the $\mathrm{NO}^{2}$ 
reduction efficiency by $\mathrm{NH}_{3}$ at various initial temperatures when $\mathrm{H}_{2} \mathrm{O}_{2}$ is added. It appears that although reduction of NO takes place at lower temperature, reduction efficiency is not very high. This is due to the fact that in this case $\mathrm{NH}_{2}$ is formed mostly by $\mathrm{OH}$ and oxidation of ammonia by $\mathrm{OH}$ is not very fast. As the temperature is raised, $\mathrm{OH}$ is formed in greater quantities, and more $\mathrm{NH}_{2}$ is produced. At still higher temperature, reduction of $\mathrm{NO}$ takes place like in normal case without $\mathrm{H}_{2} \mathrm{O}_{2}$.

\section{Reduction of NO by Hydrazine}

Hydrazine is another nitrogenous compound which is known (fig. 8(a)) to reduce No. Hydrazine dissociates to form $\mathrm{NH}_{2}$ and the rate of formation of $\mathrm{NH}_{2}$ increases with increase in temperature. Since $\mathrm{NH}_{2}$ formation here is possible at lower temperature than with $\mathrm{NH}_{3}$, NO reduction takes place at lower temperature with hydrazine than with ammonia. But $\mathrm{N}_{2} \mathrm{H}_{4}$ also generates $\mathrm{NH}_{3}$ at lower temperature, and the reduction of $N O$ is not complete until reaction temperature is reached to the level when ammonia starts forming $\mathrm{NH}_{2}$.

$$
\begin{aligned}
& \mathrm{N}_{2} \mathrm{H}_{4}+\mathrm{M} \ldots \mathrm{NH}_{2} \\
& \mathrm{NH}_{2}+\mathrm{NO} \ldots \mathrm{N}_{2}+\mathrm{H}_{2} \mathrm{O} \\
& \mathrm{NH}_{2}+\mathrm{NO} \ldots \mathrm{N}_{2} \mathrm{H}+\mathrm{OH} \\
& \mathrm{N}_{2} \mathrm{H}+\mathrm{NO} \ldots \mathrm{N}_{2}+\mathrm{HNO} \\
& \mathrm{H}+\mathrm{N}_{2} \mathrm{H}_{4} \ldots \mathrm{N}_{2} \mathrm{H}_{3}+\mathrm{H}_{2} \\
& 2 \mathrm{~N}_{2} \mathrm{H}_{3} \ldots \ldots 2 \mathrm{NH}_{3}+\mathrm{N}_{2}
\end{aligned}
$$

Table IV shows the effect of hydrazine on NO at various temperatures.

All the above discussions point out to the fact that reduction of NO in presence of ammonia takes place due to the formation of $\mathrm{NH}_{2}$ as an intermediate species. We therefore studied the NO reduction in presence of hypotehetical $\mathrm{NH}_{2}$. Figure 12 shows the temperature effect on NO reduction in presence of $\mathrm{NH}_{2}$. It appears that $\mathrm{NO}$ reduction is much less with $\mathrm{NH}_{2}$ itself than when $\mathrm{NH}_{3}$ is used; in fact, at the condition of our study, no more than 50 percent of NO is reduced at any temperature. This is due to the fact that in case of ammonia the rate determining step in $\mathrm{NO}$ reduction is the formation of $\mathrm{NH}_{2}$. In this case $\mathrm{NH}_{2}$ not only reacts with NO, it also reacts with $\mathrm{N}_{2} \mathrm{H}$ forming $\mathrm{NH}_{3}$, and $\mathrm{NH}_{3}$ does not dissociate at lower temperature. As the temperature is raised, $\mathrm{NH}_{2}{ }^{3}$ reacts with 0 atoms as well as with NO. The inajor reactions may be written as

$$
\begin{aligned}
& \mathrm{NH}_{2}+\mathrm{NO} \ldots \mathrm{N}_{2} \mathrm{H}+\mathrm{OH} \\
& \mathrm{NH}_{2}+\mathrm{NO} \ldots \mathrm{N}_{2}+\mathrm{H}_{2} \mathrm{O} \\
& \mathrm{NH}_{2}+\mathrm{N}_{2} \mathrm{H} \ldots \mathrm{NH}_{3}+\mathrm{N}_{2} \\
& \mathrm{NH}_{2}+\mathrm{O} \ldots \mathrm{H}+\mathrm{HNO} \\
& \mathrm{M}+\mathrm{HNO} \ldots \mathrm{H}+\mathrm{NO}
\end{aligned}
$$




\section{SUMMARY OF RESULTS}

Detailed chemical modeling has been performed to evaluate the effects of different chemical additives on the NOx emission in the industrial combustion systems. The exhaust stream was cooled and the additives were added to it. The chemical kinetic model used in this study was tested by other workers and was further verified by comparing the calculation results with actual experimental data. The Lsens code was used to calculate the NOx concentrations.

This study has two directions of approach. In one, convertion of $\mathrm{NOx}$ to $\mathrm{NO}_{2}$ has been considered and in the other, reduction of NOx to unreactive nitrogen has been discussed. The additives considered for $\mathrm{NOx}$ oxidation to $\mathrm{NO}_{2}$ were hydrocarbons like $\mathrm{CH}_{4}$ and $\mathrm{C}_{2} \mathrm{H}_{6}$, hydrogen and methanol. Unless used in large quantities when the mixture becomes fuel-rich, these additives do not reduce NOx to nitrogen, rather oxidize $\mathrm{N0}$ to $\mathrm{NO}_{2}$ at temperatures below $1100 \mathrm{~K}$. It is however known that $\mathrm{NO}_{2} \mathrm{Can}$ be removed from the exhaust stream by washing it with water.

$\mathrm{NH}_{3}$ reduces $\mathrm{NOx}$ to nitrogen within a short temperature range between 1000 to $1400 \mathrm{~K}$. Use of some fuels as co-additive can make the reaction take place at lower temperature. Addition of $\mathrm{H}_{2} \mathrm{O}_{2}$ also shifts the reaction temperature in the same way. The effect of fuels like $\mathrm{H}_{2}$ and methanol has been discussed. The function of these fuels is to generate heat and radicals to expedite the $\mathrm{NH}_{2}$ formation; although $\mathrm{H}_{2} \mathrm{O}_{2}$ does not generate heat, it helps to generate $\mathrm{NH}_{2}$ radicals from ammonia through radical reactions. In presence of ammonia, the ${ }^{2}$ O reduction takes place at lower temperature. Hydrazine behaves very similar to ammonia, but No reduction takes place at a lower temperature when hydrazine is used. Effect of hypothetical $\mathrm{NH}_{2}$ was tested; although NO reduction takes place at a low temperature, efficiency of NO reduction in presence of $\mathrm{NH}_{2}$ is much less than what is expected in case of ammonia.

All these reactions used in this mechanism are dependent on the concentrations of oxygen, nitrogen oxides and also the additives. The reaction rates assumed in this study also have uncertainties. The results reported here should therefore be considered as qualitative and should not be assumed exact.

\section{REFERENCES}

1. Rosenberg, H.S.; Curan, L.M., Slack, A.V., and Oxley, J.H., "Post Combustion Methods for Control of NO/x/Emissions," Progress in Energy and Combustion Science, Vol. 6, 1988, pp. 287-302.

2. Zeldovich, Y.B., "The Oxidation of Nitrogen in Combustion Explosions," Acta Physiochemica USSR, Vol. 21, 1946, pp. 577-584.

3a. Fenimore, C.P., "Reactions of Fuel-Nitrogen in Rich Flame Gases," Combustion and Flame, Vol. 26, 1976, pp. 249-256.

3b. De Soete, G.G., "Overall Reaction Rates of $\mathrm{N} 0$ and $\mathrm{N}_{2}$ Formation from Fuel Nitrogen," Fifteenth Symposium (International) on Combustion. The Combustion Institute, Pittsburgh, PA, 1975, pp. 1093-1102.

3c. Morley, C., "The Formation and Destruction of Hydrogen Cyanide from Atmospheric and Fuel Nitrogen in Rich Atmospheric-Pressure Flames," Combustion and Flame, Vol. 27, 1976, pp. 189-204. 
4. Baulch, D.L., Drysdale, D.D., Thorne, D.G., and Lloyd, A.C., Evaluated Kinetic Data for High Temperature Reactions, Vol. 1, CRC Press, Cleve Tand, OH, 1973.

5. Fenimore, C.P., "Formation of Nitric Oxide in Premixed Hydrocarbon Flames," Thirteenth Symposium (International) on Combustion, The Combustion Institute, Pittsburgh, PA, 1971, Pp. 373-380.

6. Nguyen, H.L., Bittker, D.A., and Niedzwiecki, R.W., "Investigation of Low NOx Staged Combustor Concept in High-Speed Civil Transport Engines," NASA TM-101977, 1989.

7. Sarofim, A.F., and Flagan, R.C., "NOx Control for Stationary Combustion Sources," Progress in Energy and Combustion Science, Vol. 2, 1976, pp. 1-25.

8. Lyon, R.K., "Method for the Reduction of the Concentration of NO in Combustion Efficients Using Ammonia," US. Patent No. 3900554, 1975.

8b. Turchan, 0.C., "Method of Reducing the Oxide of Nitrogen in Fossil Fuel Combustion and Combustion Gases Using Hydrazine and/or Hydrazine Compounds," US. Patent No. 4761270, 1988.

9. Arand, J.K., Muzio, L.J., and Scotter, J.G., "Urea Reduction of NOx in Combustion Effluents," US. Patent No. 4208386, 1980.

10. Perry, R.A., "NO Reduction by Using Sublimation of Cyanuric Acid," US. Patent No. $4731231,1988$.

11. Siebers, D.L., and Caton, J., "Reduction of Nitrogen Oxides by the Raprenox Process," Paper No. 53, Central States Station/The Combustion Institute Meeting, Indianapolis, IN, May $19 \overline{8} 8$.

12. Wada, Y., and Yamatsuta, K., "Waste Gas Treatment Method," Japanese Early Patent Disclosure No. 54028771, 1979.

13. Murakami, N., Kojima, N., and Hasiguchi, M., "Oxidation of Nitric Oxide to Monometric Nitrogen Dioxide in Fuel Gas. I. Oxidation by Addition of Methanol," Nenryo Kyo Kaishi, Vol. 61, 1982, pp. 276-284.

14. Miller, J.A., and Bownan, C.T., "Mechanism and Modeling of Nitrogen Chemistry in Combustion," Progess in Energy and Combustion Science, Vol. 15, 1989, pp. 287-338.

15. Bittker, D.A., Scullin, V.J., "GCKP84-General Chemical Kinetics Code for GasPhase Flow and Batch Processes Including Heat Transfer Effects," NASA TP-2320, 1984.

16. Kee, R.J., Rupley, F.M., and Miller, J.A., "The Chemkin Thermodynamic Data Base," Sandia Report, SAND87-8215, 1987.

17. Bartok, W., Engleman, V.S., Goldstein, R., and Delvalle, E.G., "Basic Kinetic Studies and Modeling at Nitrogen Oxide Formation in Combustion Process," AIChE Symposium Series, Vol. 68, No. 126, 1972, pp. 30-32.

18. Westbrook, C.K., and Dreyer, F.L., "Chemical Kinetic Modeling of Hydrocarbon Combustion," Progress in Energy and Combustion Science, Vol. 10, 1984, pp. 1-57. 
19. Lyon, R.K., and Benn, D., "Kinetics of The NO-NH $\mathrm{H}_{3}-\mathrm{O}_{2}$ Reaction," Seventeenth Symposium (International) on Combustion, The Combustion Institute, Pittsburgh, PA, 1979, pp. 601-610.

20. Fenimore, C.P., "Destruction of $\mathrm{NO}$ by $\mathrm{NH}_{3}$ in Lean Burnt Gas," Combustion and Flame, Vol. 37,1980, pp. 245-250.

21. Kimball-Linne, M.A., and Hanson, R.K., "Combustion-Driven Flow Reactor Studies of Thermal DeNOx Reactions Kinetics," Combustion and Flame, Vol. 64, 1986, pp. 337-351.

22. Yano, T., "Behavior of Methanol and Formaldehyde in Burnt Gas from Methanol Combustion: Effects of Nitric Oxide on Oxidation Reaction, " JSME Bulletin. Vol. 26, No. 213, 1983, pp. 406-413.

23. Lyon, R.K., Cole, J.A., Kramlich, J.C., and Chen, S.L., "The Selective Reduction of $\mathrm{SO}_{3}$ to $\mathrm{SO}_{2}$ and the Oxidation of $\mathrm{NO}$ to $\mathrm{NO}_{2}$ by Methanol," Combustion and Flame, Vol. 81, 1990, pp. 30-39.

24. Muzio, L.J., and Arand, J.K., "Gas Phase Decomposition of Nitric Oxide in Combustion Products," Sixteenth Symposium (International) on Combustion. The Combustion Institute, Pittsburgh, PA, 1977, pp. 199-208. 
TABLE I

\begin{tabular}{|c|c|c|c|c|c|c|c|c|c|}
\hline $\begin{array}{l}\mathrm{M} \\
\mathrm{CO}\end{array} \stackrel{+2.0 \mathrm{CH} 3}{\text { THIRDBODY }}$ & \multicolumn{2}{|c|}{$\begin{array}{l}+2.0 \mathrm{CH} 3 \\
\mathrm{DY}\end{array}$} & $=$ & $\mathrm{C} 2 \mathrm{H} 6$ & + & M & $9.03 E+16$ & -1.2 & 654. \\
\hline $\begin{array}{l}\text { CO } \\
\text { END }\end{array}$ & & 0 & & 2. & & $\mathrm{CO} 2$ & 3.0 & $\mathrm{H} 2 \mathrm{C}$ & 5.0 \\
\hline $\begin{array}{l}\mathrm{CH} 3 \\
\text { THIRDB }\end{array}$ & $\begin{array}{l}+ \\
D Y\end{array}$ & $\mathrm{H}$ & $=$ & $\mathrm{CH} 4$ & + & M & $6.00 E+16$ & -1 & (2) \\
\hline $\begin{array}{l}\text { CO } \\
\text { END }\end{array}$ & & 0 & & 2. & & $\mathrm{CO} 2$ & 3.0 & $\mathrm{H} 2 \mathrm{C}$ & 5.0 \\
\hline $\mathrm{CH} 4$ & + & 02 & $=$ & $\mathrm{CH} 3$ & + & $\mathrm{HO2}$ & $7.90 E+13$ & 0. & $56000 .(3)$ \\
\hline $\mathrm{CH} 4$ & + & $H$ & $=$ & $\mathrm{CH} 3$ & + & $\mathrm{H} 2$ & $2.20 E+04$ & 3. & $8750 .(4)$ \\
\hline $\mathrm{CH} 4$ & + & $\mathrm{OH}$ & $=$ & $\mathrm{CH} 3$ & + & $\mathrm{H} 2 \mathrm{O}$ & $1.60 \mathrm{E}+06$ & 2.1 & $2460 .(5)$ \\
\hline $\mathrm{CH} 4$ & + & 0 & $=$ & $\mathrm{CH} 3$ & + & $\mathrm{OH}$ & $1.02 E+09$ & 1.5 & $8604 .(6)$ \\
\hline $\mathrm{CH} 4$ & + & $\mathrm{HO} 2$ & $=$ & $\mathrm{CH} 3$ & + & $\mathrm{H} 202$ & $1.80 E+11$ & 0 . & $18700 .(7)$ \\
\hline $\mathrm{CH} 3$ & + & $\mathrm{HO} 2$ & $=$ & $\mathrm{CH} 30$ & + & $\mathrm{OH}$ & $2.00 E+13$ & 0 & $0 . \quad(8)$ \\
\hline $\mathrm{CH} 3$ & + & 02 & $=$ & $\mathrm{CH} 30$ & + & 0 & $2.05 E+19$ & -1.6 & 29229 (9) \\
\hline $\mathrm{CH} 3$ & + & 0 & $=$ & $\mathrm{CH} 2 \mathrm{O}$ & + & $H$ & $8.00 E+13$ & 0 & 0. (10) \\
\hline $\mathrm{CH} 2 \mathrm{OH}$ & + & $\mathrm{H}$ & $=$ & $\mathrm{CH} 3$ & + & $\mathrm{OH}$ & $1.00 E+14$ & 0. & $0 .(11)$ \\
\hline M & + & $\mathrm{CH} 2 \mathrm{OH}$ & $=$ & $\mathrm{CH} 2 \mathrm{O}$ & + & $\mathrm{H}$ & $1.00 E+14$ & 0 . & $25000 .(12)$ \\
\hline $\mathrm{CH} 2 \mathrm{OH}$ & + & $\mathrm{H}$ & $=$ & $\mathrm{CH} 2 \mathrm{O}$ & + & $\mathrm{H} 2$ & $2.00 E+13$ & 0 . & $0 .(13)$ \\
\hline $\mathrm{CH} 2 \mathrm{OH}$ & + & $\mathrm{OH}$ & $=$ & $\mathrm{CH} 2 \mathrm{O}$ & + & $\mathrm{H} 2 \mathrm{O}$ & $1.00 E+13$ & 0 . & $0 .(14)$ \\
\hline $\mathrm{CH} 2 \mathrm{OH}$ & + & 0 & $=$ & $\mathrm{CH} 2 \mathrm{O}$ & + & $\mathrm{OH}$ & $1.00 E+13$ & 0 . & $0 .(15)$ \\
\hline $\mathrm{CH} 2 \mathrm{OH}$ & + & 02 & $=$ & $\mathrm{CH} 2 \mathrm{O}$ & + & $\mathrm{HO} 2$ & $1.48 E+13$ & 0 . & $1500 .(16)$ \\
\hline M & + & $\mathrm{CH} 3 \mathrm{OH}$ & $=$ & $\mathrm{CH} 3$ & + & $\mathrm{OH}$ & $3.02 E+18$ & 0 . & $80000 .(17)$ \\
\hline$H$ & + & $\mathrm{CH} 30 \mathrm{H}$ & $=$ & $\mathrm{CH} 3$ & + & $\mathrm{H} 2 \mathrm{O}$ & $2.00 E+12$ & 0. & $5300 .(18)$ \\
\hline$H$ & + & $\mathrm{CH} 3 \mathrm{OH}$ & $=$ & $\mathrm{CH} 2 \mathrm{OH}$ & + & $\mathrm{H} 2$ & $3.02 E+13$ & 0. & $7000 .(19)$ \\
\hline $\mathrm{OH}$ & + & $\mathrm{CH} 3 \mathrm{OH}$ & $=$ & $\mathrm{CH} 2 \mathrm{OH}$ & + & $\mathrm{H} 2 \mathrm{O}$ & $3.98 \mathrm{E}+12$ & 0 . & $2000 .(20)$ \\
\hline $\mathrm{CH} 30$ & + & $\mathrm{H}$ & $=$ & $\mathrm{CH} 3$ & + & $\mathrm{OH}$ & $1.00 E+14$ & 0 . & $0 . \quad(21)$ \\
\hline $\mathrm{CH} 3 \mathrm{OH}$ & + & 02 & $=$ & $\mathrm{CH} 2 \mathrm{OH}$ & + & $\mathrm{HO2}$ & $3.98 \mathrm{E}+10$ & 0. & 50910. (22) \\
\hline $\mathrm{CH} 3 \mathrm{OH}$ & + & 0 & $=$ & $\mathrm{CH} 2 \mathrm{OH}$ & + & $\mathrm{OH}$ & $1.70 E+12$ & 0 . & 2290. (23) \\
\hline $\mathrm{CH} 3 \mathrm{OH}$ & + & $\mathrm{CH} 3$ & $=$ & $\mathrm{CH} 2 \mathrm{OH}$ & + & $\mathrm{CH} 4$ & $1.82 \mathrm{E}+11$ & 0 . & $9800 .(24)$ \\
\hline $\mathrm{CH} 3 \mathrm{OH}$ & + & $\mathrm{HO2}$ & $=$ & $\mathrm{CH} 2 \mathrm{OH}$ & + & $\mathrm{H} 2 \mathrm{O} 2$ & $6.31 E+12$ & 0 . & $19360 .(25)$ \\
\hline $\mathrm{CH} 3$ & + & $\mathrm{OH}$ & $=$ & $\mathrm{CH} 2$ & + & $\mathrm{H} 2 \mathrm{O}$ & $7.50 E+06$ & 2. & $5000 .(26)$ \\
\hline $\mathrm{CH} 3$ & + & $\mathrm{H}$ & $=$ & $\mathrm{CH} 2$ & + & $\mathrm{H} 2$ & $9.00 E+13$ & 0 . & $15100 .(27)$ \\
\hline$M$ & + & $\mathrm{CH} 30$ & $=$ & $\mathrm{CH} 2 \mathrm{O}$ & + & $\mathrm{H}$ & $1.00 E+14$ & 0. & $25000 .(28)$ \\
\hline $\mathrm{CH} 30$ & + & $\mathrm{H}$ & $=$ & $\mathrm{CH} 2 \mathrm{O}$ & + & $\mathrm{H} 2$ & $2.00 E+13$ & 0. & $0 .(29)$ \\
\hline $\mathrm{CH} 30$ & + & $\mathrm{OH}$ & $=$ & $\mathrm{CH} 2 \mathrm{O}$ & + & $\mathrm{H} 2 \mathrm{O}$ & $1.00 \mathrm{E}+13$ & 0 & $0 . \quad(30)$ \\
\hline $\mathrm{CH} 30$ & + & 0 & $=$ & $\mathrm{CH} 2 \mathrm{O}$ & + & $\mathrm{OH}$ & $1.00 E+13$ & 0 & $0 .(31)$ \\
\hline $\mathrm{CH} 30$ & + & 02 & $=$ & $\mathrm{CH} 2 \mathrm{O}$ & + & $\mathrm{HO2}$ & $6.30 E+10$ & 0 & $2600 .(32)$ \\
\hline $\mathrm{CH} 2$ & + & $\mathrm{H}$ & $=$ & $\mathrm{CH}$ & + & $\mathrm{H} 2$ & $1.00 E+18$ & -1.56 & $0 . \quad(33)$ \\
\hline $\mathrm{CH} 2$ & + & $\mathrm{OH}$ & $=$ & $\mathrm{CH}$ & + & $\mathrm{H} 2 \mathrm{O}$ & 1. $13 E+07$ & 2. & $3000 .(34)$ \\
\hline $\mathrm{CH} 2$ & + & $\mathrm{OH}$ & $=$ & $\mathrm{CH} 2 \mathrm{O}$ & + & $\mathrm{H}$ & $2.50 E+13$ & 0 . & $0 . \quad$ (35) \\
\hline $\mathrm{CH}$ & + & 02 & $=$ & $\mathrm{HCO}$ & + & 0 & $3.30 E+13$ & 0 . & 0. (36) \\
\hline $\mathrm{CH}$ & + & 0 & $=$ & $\mathrm{CO}$ & + & $H$ & $5.70 E+13$ & 0 . & $0 .(37)$ \\
\hline $\mathrm{CH}$ & + & $\mathrm{OH}$ & $=$ & $\mathrm{HCO}$ & + & $\mathrm{H}$ & $3.00 E+13$ & 0. & $0 .(38)$ \\
\hline $\mathrm{CH}$ & + & $\mathrm{CO} 2$ & $=$ & $\mathrm{HCO}$ & + & $\mathrm{CO}$ & $3.40 E+12$ & 0 . & 690. (39) \\
\hline $\mathrm{CH}$ & + & $H$ & $=$ & C & + & $\mathrm{H} 2$ & $1.50 E+14$ & 0 & $0 . \quad(40)$ \\
\hline $\mathrm{CH}$ & + & $\mathrm{H} 2 \mathrm{O}$ & $=$ & $\mathrm{CH} 2 \mathrm{O}$ & + & $H$ & $1.17 E+15$ & -.75 & $0 . \quad(41)$ \\
\hline $\mathrm{CH}$ & + & $\mathrm{CH} 2 \mathrm{O}$ & $=$ & $\mathrm{CH} 2 \mathrm{CO}$ & + & $H$ & $9.46 E+13$ & 0 & $-515 .(42)$ \\
\hline $\mathrm{CH}$ & + & $\mathrm{CH} 2$ & $=$ & $\mathrm{C} 2 \mathrm{H} 2$ & + & $H$ & $4.00 E+13$ & 0 . & $0 . \quad(43)$ \\
\hline $\mathrm{CH}$ & + & $\mathrm{CH} 3$ & $=$ & $\mathrm{C} 2 \mathrm{H} 3$ & + & $H$ & $3.00 E+13$ & 0 . & $(44)$ \\
\hline $\mathrm{CH}$ & + & $\mathrm{CH} 4$ & $=$ & $\mathrm{C} 2 \mathrm{H} 4$ & + & $H$ & $6.00 E+13$ & 0 . & $0 . \quad(45)$ \\
\hline C & + & 02 & $=$ & $\mathrm{CO}$ & + & 0 & $2.00 E+13$ & 0 . & $0 .(46)$ \\
\hline C & + & $\mathrm{OH}$ & $=$ & $\mathrm{CO}$ & + & $H$ & $5.00 E+13$ & 0 . & $0 .(47)$ \\
\hline C & + & $\mathrm{CH} 3$ & $=$ & $\mathrm{C} 2 \mathrm{H} 2$ & + & $H$ & $5.00 E+13$ & 0 . & $0 .(48)$ \\
\hline C & + & $\mathrm{CH} 2$ & $=$ & $\mathrm{C} 2 \mathrm{H}$ & + & $H$ & $5.00 E+13$ & 0. & $0 .(49)$ \\
\hline $\mathrm{CH} 2$ & + & $\mathrm{CO} 2$ & $=$ & $\mathrm{CH} 2 \mathrm{O}$ & + & $\mathrm{CO}$ & $1.10 \mathrm{E}+11$ & 0 . & $1000 .(50)$ \\
\hline $\mathrm{CH} 2$ & + & 0 & & & + & $\mathrm{CO}$ & $5.00 E+13$ & 0 . & $0 . \quad(51)$ \\
\hline $\mathrm{CH} 2$ & + & 0 & $=$ & $\mathrm{CO}$ & + & $\mathrm{H} 2$ & $3.00 E+13$ & 0 . & $(52)$ \\
\hline
\end{tabular}




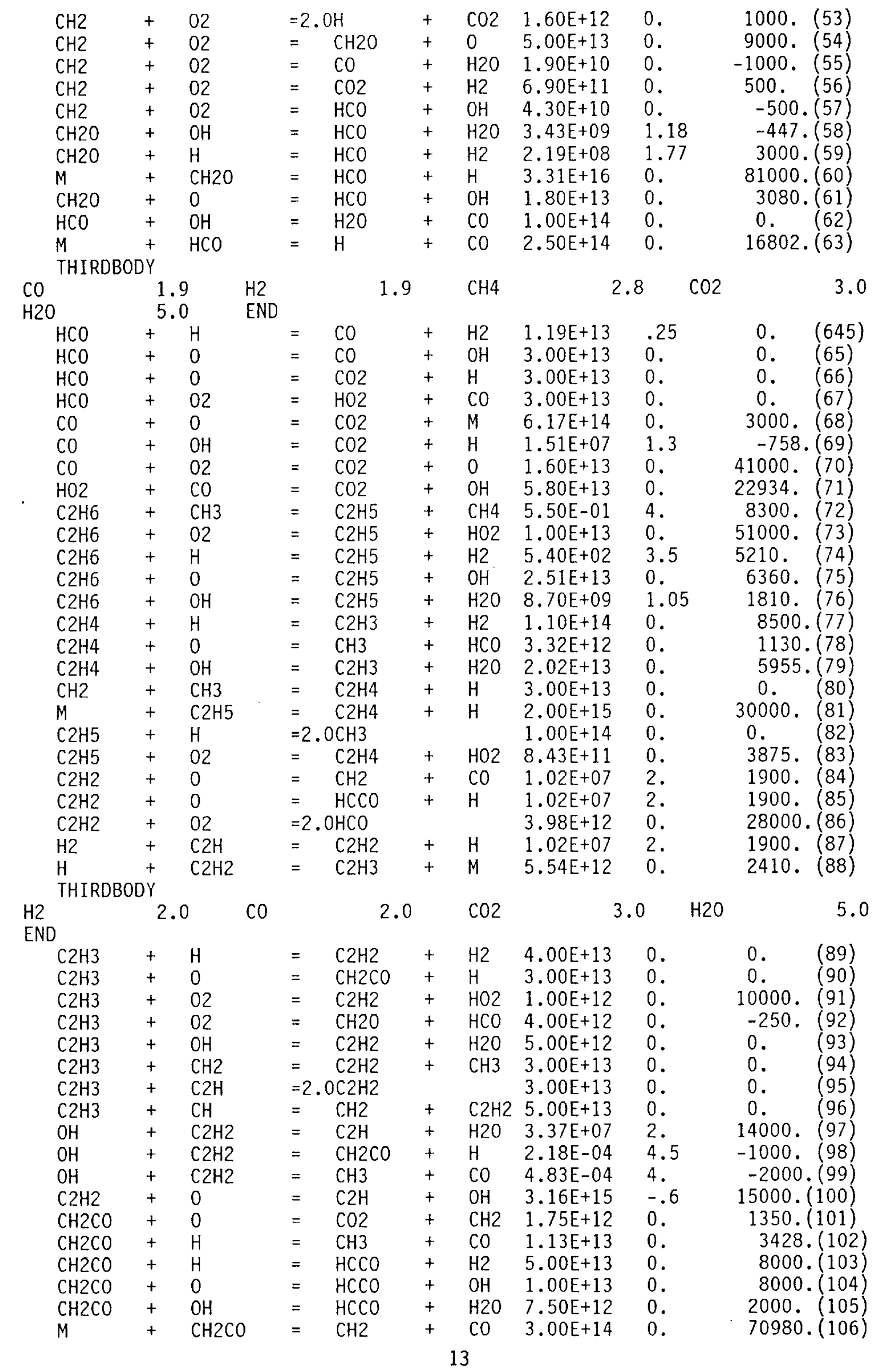




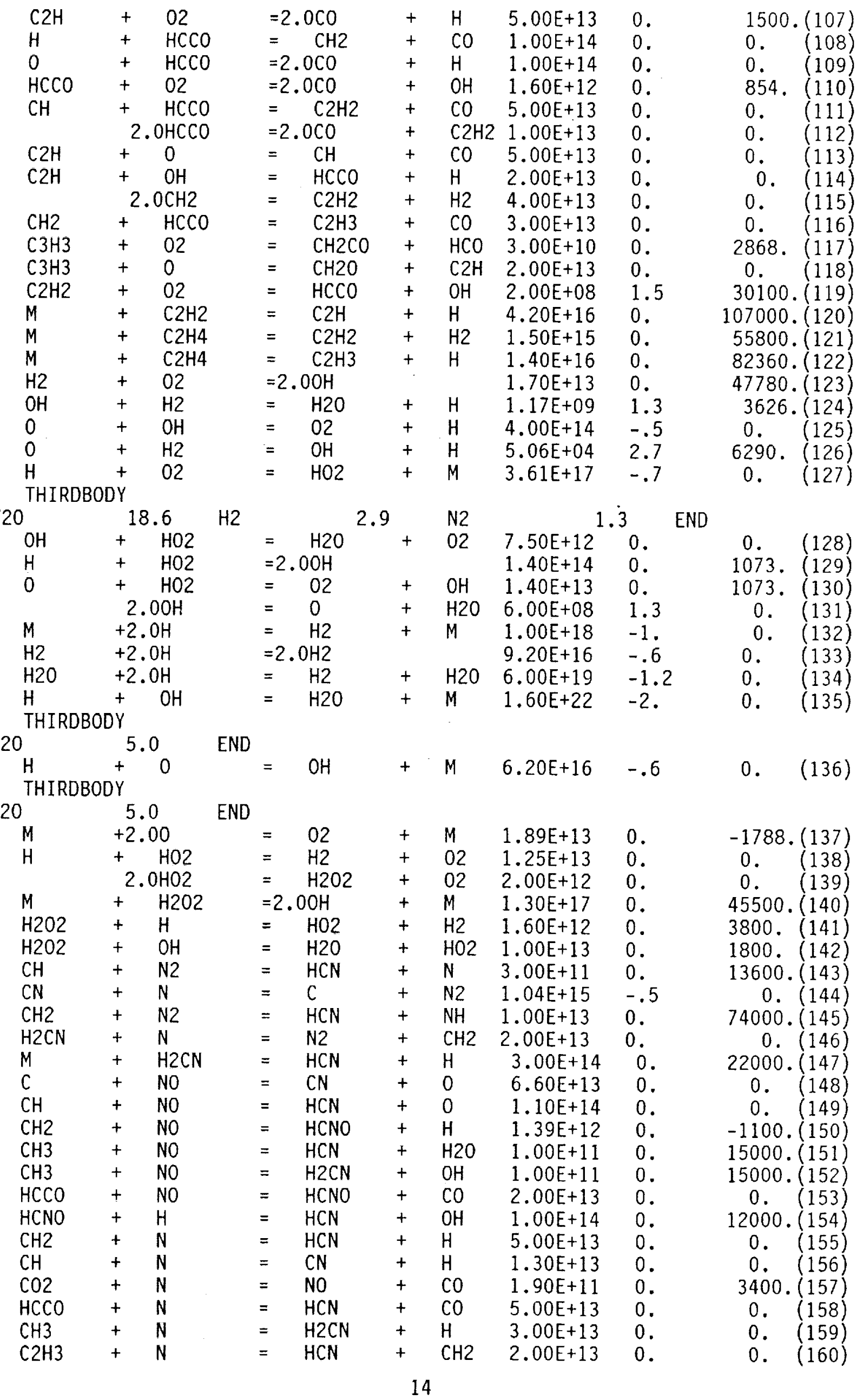




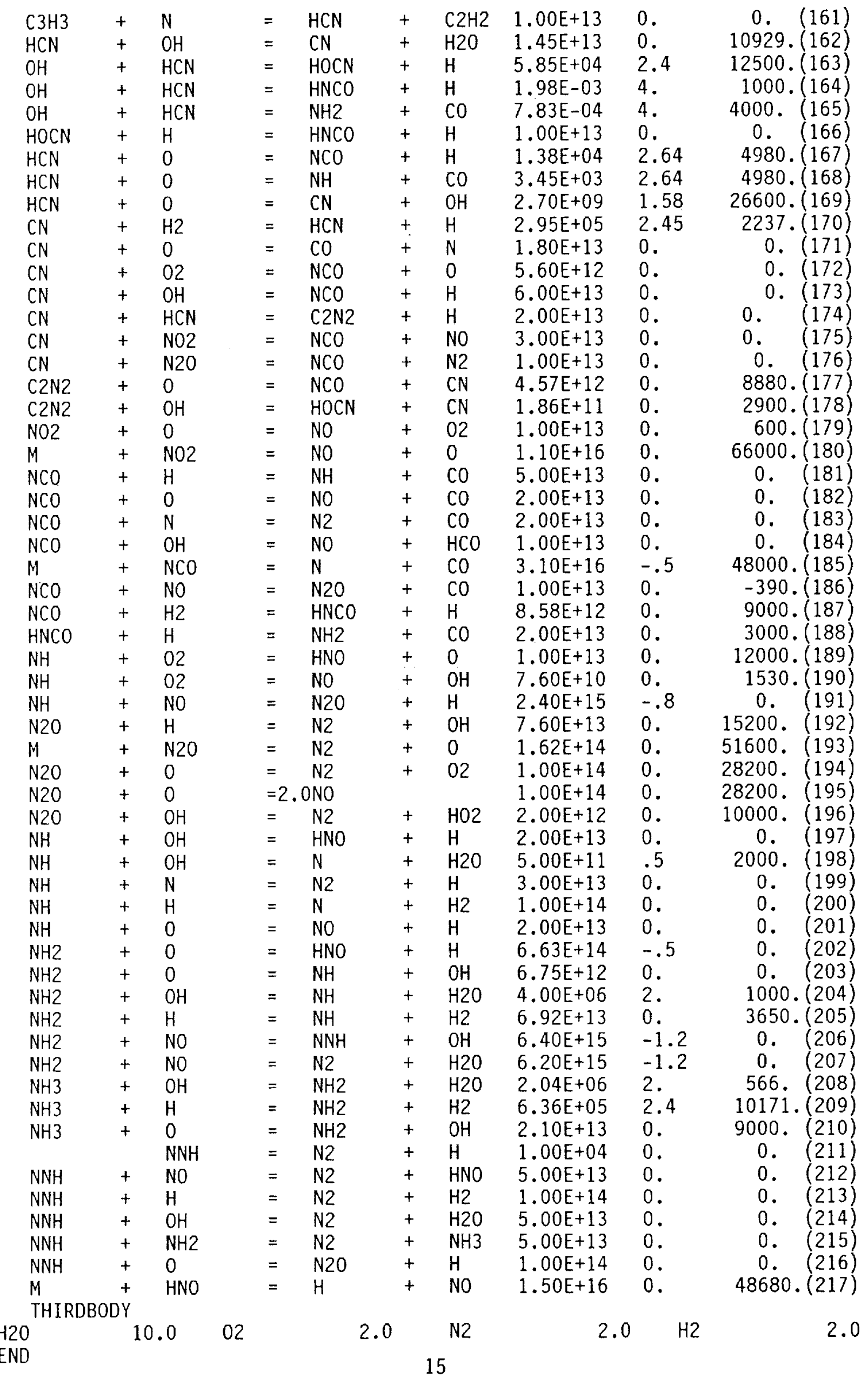




\begin{tabular}{|c|c|c|c|c|c|c|c|c|c|}
\hline HNO & $\mathrm{OH}$ & & NO & + & $\mathrm{H} 2 \mathrm{O}$ & $3.60 E+13$ & 0 . & 0. & (218) \\
\hline HNO & $\mathrm{H}$ & & $=\quad H 2$ & + & NO & $5.00 E+12$ & 0. & 0 & (219) \\
\hline M & $\mathrm{N} 2 \mathrm{H} 4$ & & $=2.0 \mathrm{NH} 2$ & + & M & $3.98 E+13$ & 0 . & 26673 . & $(220)$ \\
\hline H & $\mathrm{N} 2 \mathrm{H} 4$ & & $=\quad \mathrm{N} 2 \mathrm{H} 3$ & + & $\mathrm{H} 2$ & $3.50 E+11$ & 0 . & 0 & (221) \\
\hline $\mathrm{N} 2 \mathrm{H} 3$ & $\mathrm{~N} 2 \mathrm{H} 3$ & & $=2.0 \mathrm{NH} 3$ & + & $\mathrm{N} 2$ & $1.30 E+14$ & 0 . & 0 . & (222) \\
\hline $\mathrm{H}$ & $\mathrm{N} 2 \mathrm{H} 4$ & & $=\mathrm{NH} 2$ & + & $\mathrm{NH} 3$ & $3.50 E+11$ & 0 & 0 & (223) \\
\hline \multirow[t]{2}{*}{ HNO } & $+\quad \mathrm{NH} 2$ & & $\mathrm{NH} 3$ & + & NO & $2.00 E+13$ & 0. & 1000 & $(224)$ \\
\hline & \multicolumn{2}{|l|}{ 2.0HNO } & $\mathrm{N} 20$ & + & $\mathrm{H} 2 \mathrm{O}$ & $3.95 E+12$ & 0 . & 5000 & $(225)$ \\
\hline HNO & \multicolumn{2}{|l|}{ NO } & $\mathrm{N} 20$ & + & $\mathrm{OH}$ & $2.00 E+12$ & 0. & 26000 . & $(226)$ \\
\hline $\mathrm{N}$ & \multicolumn{2}{|l|}{ NO } & $\mathrm{N} 2$ & + & 0 & $3.27 E+12$ & .3 & 0 & $(227)$ \\
\hline$N$ & \multicolumn{2}{|l|}{02} & NO & + & 0 & $6.40 E+09$ & 1. & 6280. & $(228)$ \\
\hline$N$ & \multicolumn{2}{|l|}{$\mathrm{OH}$} & NO & + & $\mathrm{H}$ & $3.80 E+13$ & 0. & 0 & (229) \\
\hline HO2 & \multicolumn{2}{|l|}{ NO } & NO2 & + & $\mathrm{OH}$ & $2.11 E+11$ & 0 . & -479 & $(230)$ \\
\hline N02 & \multicolumn{2}{|l|}{$\mathrm{H}$} & NO & + & $\mathrm{OH}$ & $3.50 E+14$ & 0. & 1500 . & $(231)$ \\
\hline \multirow[t]{2}{*}{$\mathrm{NH} 2$} & \multicolumn{2}{|l|}{$\mathrm{NH}$} & $=\quad \mathrm{N} 2 \mathrm{H} 2$ & + & $\mathrm{H}$ & $5.00 E+13$ & 0. & 0. & (232) \\
\hline & \multicolumn{2}{|l|}{$2.0 \mathrm{NH}$} & $=2.0 \mathrm{H}$ & + & N2 & $7.20 E+13$ & 0. & 0. & (233) \\
\hline $\mathrm{NH} 2$ & \multicolumn{2}{|l|}{$\mathrm{N}$} & $=2.0 \mathrm{H}$ & + & $\mathrm{N} 2$ & $7.20 E+13$ & 0. & 0 & $(234)$ \\
\hline \multicolumn{7}{|c|}{ THIRDBODY } & & & $(235)$ \\
\hline & 15.0 & 02 & \multicolumn{2}{|c|}{2.0} & $\mathrm{~N} 2$ & \multicolumn{2}{|c|}{2.0} & $\mathrm{H} 2$ & 2.0 \\
\hline $\mathrm{N} 2 \mathrm{H} 2$ & + & & $\mathrm{NNH}$ & + & $\mathrm{H} 2$ & $5.00 E+13$ & 0 . & 0 . & $(236)$ \\
\hline $\mathrm{N} 2 \mathrm{H} 2$ & + & & $\mathrm{NH} 2$ & + & NO & $1.00 E+13$ & 0 . & 0 & (237) \\
\hline $\mathrm{N} 2 \mathrm{H} 2$ & 0 & & $\mathrm{NNH}$ & + & $\mathrm{OH}$ & $2.00 E+13$ & 0 . & 1000. & (238) \\
\hline $\mathrm{N} 2 \mathrm{H} 2$ & $\mathrm{OH}$ & & NNH & + & $\mathrm{H} 2 \mathrm{O}$ & $1.00 E+13$ & 0. & 1000. & (239) \\
\hline $\mathrm{N} 2 \mathrm{H} 2$ & NO & & $\mathrm{N} 20$ & + & $\mathrm{NH} 2$ & $3.00 E+12$ & 0 & 0 & (240) \\
\hline $\mathrm{N} 2 \mathrm{H} 2$ & $\mathrm{NH}$ & & NNH & + & $\mathrm{NH} 2$ & $1.00 E+13$ & 0. & 1000 & (241) \\
\hline $\mathrm{N} 2 \mathrm{H} 2$ & $+\quad \mathrm{NH} 2$ & & $\mathrm{NH} 3$ & + & NNH & $1.00 E+13$ & 0. & 1000. & (242) \\
\hline & $2.0 \mathrm{NH} 2$ & & $\mathrm{~N} 2 \mathrm{H} 2$ & + & $\mathrm{H} 2$ & $5.00 \mathrm{E}+11$ & 0 . & 0 . & (243) \\
\hline $\mathrm{NH} 2$ & $+\quad 02$ & & HNO & + & $\mathrm{OH}$ & $4.50 \mathrm{E}+12$ & 0. & 25000 . & $(244)$ \\
\hline
\end{tabular}


TABLE II. - EFFECT OF TEMPERATURE ON THE CONVERTION OF NO TO $\mathrm{NO}_{2}$

[Emission from (WSR) combustion of methane at residence time around $1.5 \mathrm{msec}$ (containing about 10 percent oxygen and hydrocarbon fractions) was used in this calculation.]

\begin{tabular}{|c|c|c|c|c|c|c|}
\hline $\begin{array}{c}\text { Temperature, } \\
\mathrm{K}\end{array}$ & \multicolumn{2}{|c|}{$\begin{array}{c}\mathrm{N} 0, \\
\mathrm{ppm}\end{array}$} & \multicolumn{2}{c|}{$\begin{array}{c}\mathrm{N}_{2}, \\
\mathrm{ppm}\end{array}$} & \multicolumn{2}{c|}{$\begin{array}{c}\text { N0x, } \\
\mathrm{ppm}\end{array}$} \\
\cline { 2 - 7 } & $300 \mathrm{~ms}$ & $1 \mathrm{sec}$ & $300 \mathrm{~ms}$ & $1 \mathrm{sec}$ & $300 \mathrm{~ms}$ & $1 \mathrm{sec}$ \\
\hline 700 & 918 & 914 & 81.5 & 85 & 1000 & 1000 \\
800 & 940 & 938 & 59.0 & 62 & 1000 & 1000 \\
900 & 956 & 953 & 43.0 & 46 & 1000 & 1000 \\
1000 & 972 & 971 & 27.0 & 28 & 1000 & 1000 \\
1100 & 986 & 987 & 13.0 & 13 & 1000 & 1000 \\
1200 & 993 & 991 & 6.0 & 9 & 1000 & 1000 \\
\hline
\end{tabular}

TABLE III. - COMPARISON OF EFFICIENCIES OF DIFFERENT ADDIVITIVES TO OXIDIZE NO TO $\mathrm{NO}_{2}$

$[\mathrm{NO}=500 \mathrm{ppm}$ and time of reaction $=1 \mathrm{sec}$. $\mathrm{H}_{2}=3091 \mathrm{ppm}_{1} \mathrm{CH}_{4}=1000 \mathrm{ppm}, \mathrm{C}_{2} \mathrm{H}_{6}=$ $500 \mathrm{ppm}$ and $\mathrm{CH}_{3} \mathrm{OH}^{4}=500 \mathrm{ppm} ; 0 x y g$ en $=$ 4.2 percent.]

\begin{tabular}{|c|r|r|r|r|}
\hline \multirow{2}{*}{ Temperature, $\mathrm{K}$} & \multicolumn{4}{|c|}{$\mathrm{NO} /(\mathrm{NO})_{1}$} \\
\cline { 2 - 5 } & \multicolumn{1}{|c|}{$\mathrm{CH}_{4}$} & \multicolumn{1}{|c|}{$\mathrm{H}_{2}$} & \multicolumn{1}{c|}{$\mathrm{C}_{2} \mathrm{H}_{6}$} & $\mathrm{CH}_{3} \mathrm{OH}$ \\
\hline 700 & ---- & 0.71 & 0.99 & 0.99 \\
800 & --- & .80 & .99 & .99 \\
900 & 0.58 & .86 & .79 & .98 \\
950 & .65 & --- & .36 & .87 \\
1000 & .96 & .93 & .06 & .45 \\
1050 & .98 & --- & .05 & .12 \\
1100 & ---- & .01 & .62 & .07 \\
1200 & --- & --- & --- & .88 \\
\hline
\end{tabular}


TABLE IV. - EFFECT OF HYDRAZINE ON THE REDUCTION OF NO AT DIFFERENT

TEMPERATURES

[400 ppm N $\mathrm{H}_{4}$ and $500 \mathrm{ppm} \mathrm{N0;} 4.2$ percent oxygen.]

\begin{tabular}{|c|r|c|c|}
\hline \multirow{2}{*}{$\begin{array}{c}\text { Temperature } \\
\mathrm{K}\end{array}$} & \multicolumn{3}{|c|}{ N0/(NOx) } \\
\cline { 2 - 4 } & $\begin{array}{c}25 \\
\mathrm{msec}\end{array}$ & $300 \mathrm{msec}$ & $1 \mathrm{sec}$ \\
\hline 1050 & 0.37 & 0.31 & 0.17 \\
1100 & .41 & .21 & .06 \\
1150 & .42 & .11 & .02 \\
1200 & .36 & .06 & .038 \\
\hline
\end{tabular}




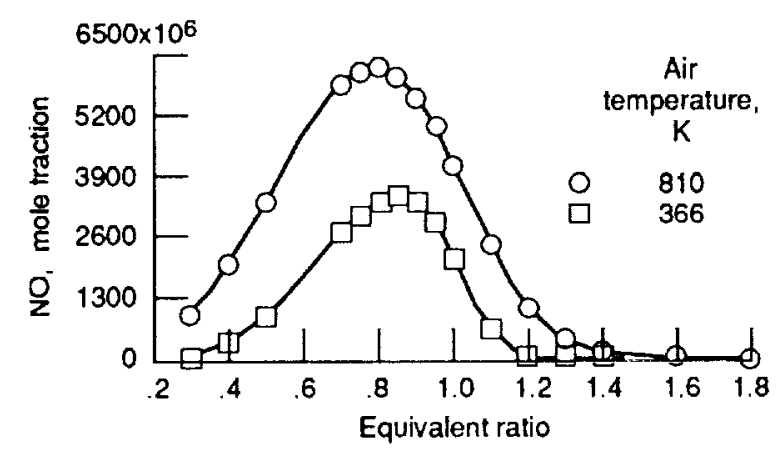

Figure 1.-Equilibrium concentrations of $\mathrm{NO}$ at different fuel-air ratios. Fuel, $\mathrm{CH}_{4}$; temperature, $366 \mathrm{~K}$.

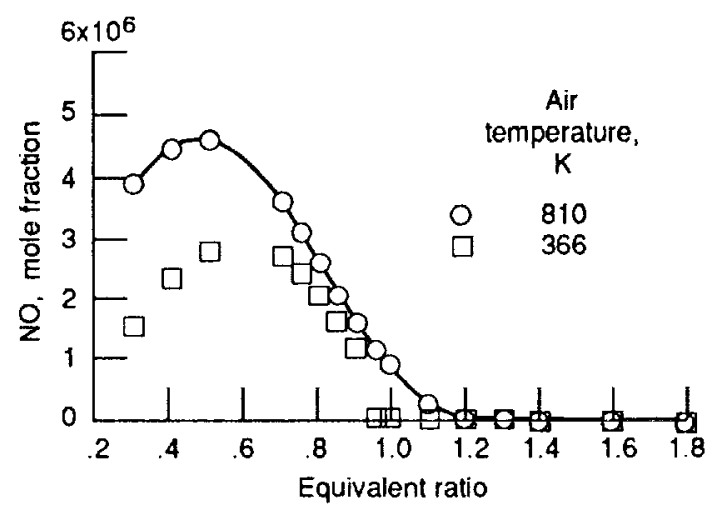

Figure 2.-Equilibrium concentrations of $\mathrm{NO}_{2}$ at different fuel-air ratios. Fuel, $\mathrm{CH}_{4}$; temperature, $366 \mathrm{~K}$.

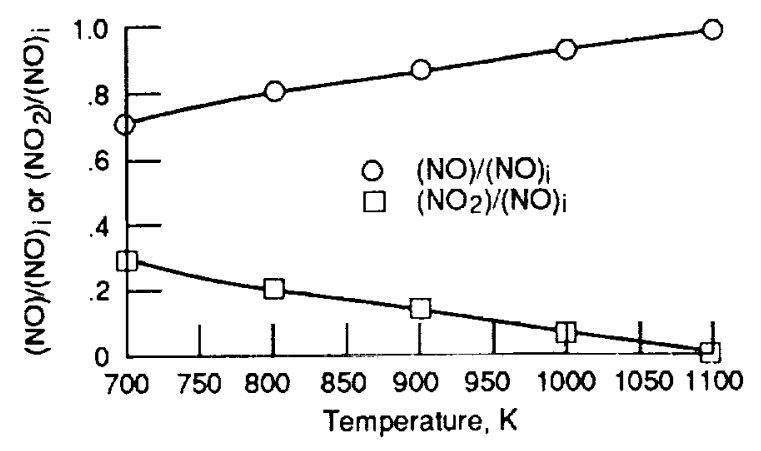

(a) $500 \mathrm{ppm} \mathrm{NO}$ and $3090 \mathrm{ppm} \mathrm{H}_{2}$.

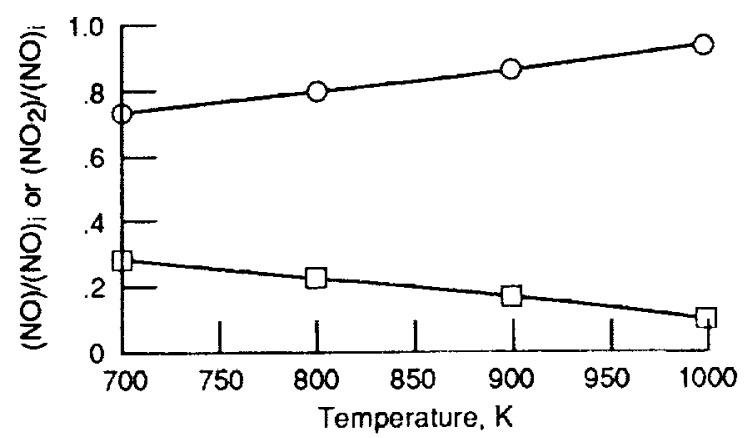

(b) $815 \mathrm{ppm} \mathrm{NO}$ and $4300 \mathrm{ppm} \mathrm{H}$. Oxygen, $17 \%$.

Figure 3.-Effect of hydrogen on $\mathrm{NO}$ at various temperatures. Time, $1 \mathrm{sec}$.

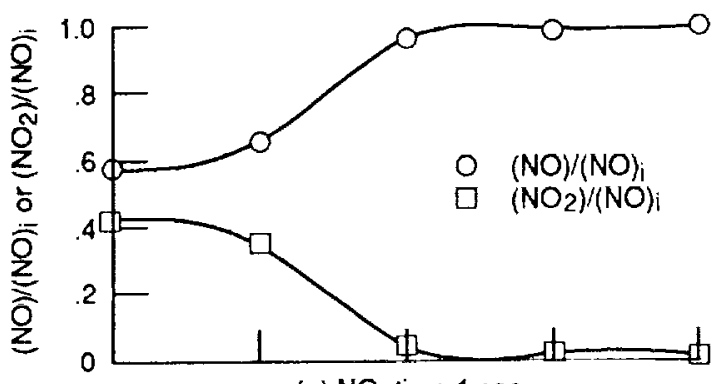

(a) NO; time.1 sec.

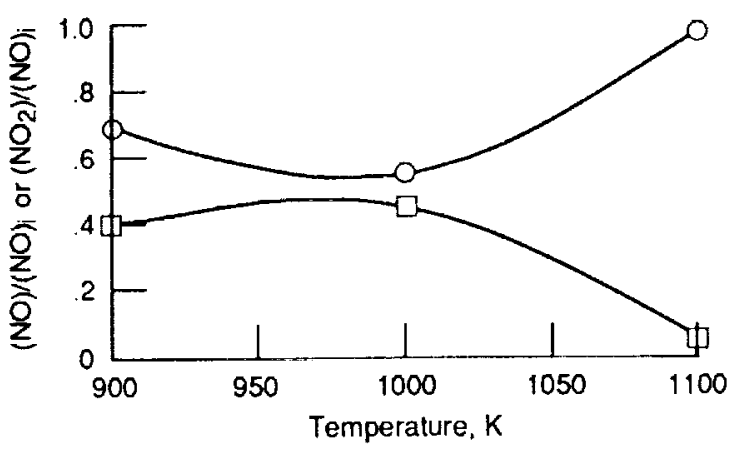

(b) NOx; time, 300 msec; oxygen, $10 \%$.

Figure 4.-Effect of methane. $500 \mathrm{ppm} \mathrm{NO}$ and $1000 \mathrm{ppm} \mathrm{CH}_{4}$. 


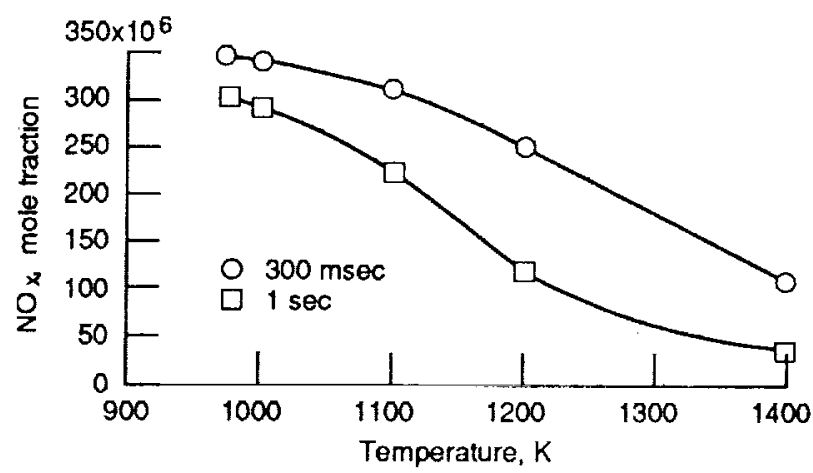

Figure 5.-Effect of methane $(\phi=2.0)$ on NO.
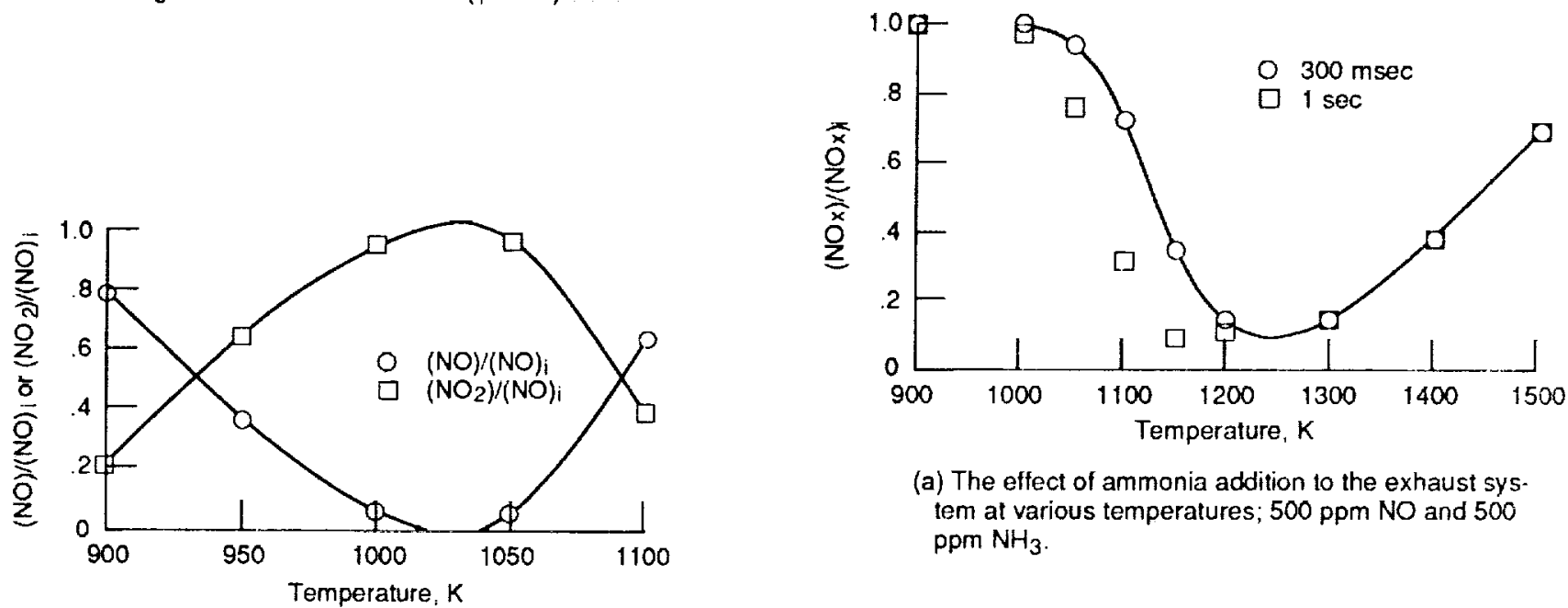

(a) The effect of ammonia addition to the exhaust sys tem at various temperalures; $500 \mathrm{ppm} \mathrm{NO}$ and 500 ppm $\mathrm{NH}_{3}$

(a) $\mathrm{NO}_{x} ; 500 \mathrm{ppm} \mathrm{NO}$ and $500 \mathrm{ppm} \mathrm{C}_{2} \mathrm{H}_{6}$.

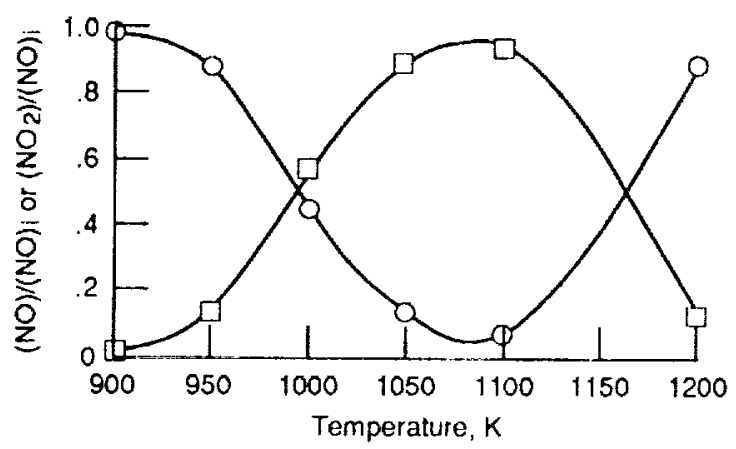

(b) $\mathrm{NO} ; 500 \mathrm{ppm} \mathrm{NO}$ and $500 \mathrm{ppm} \mathrm{CH}_{3} \mathrm{OH}$.

Figure 6.-Oxidation of $\mathrm{NO}$ to $\mathrm{NO}_{2} ;$ time, $1 \mathrm{sec}$.

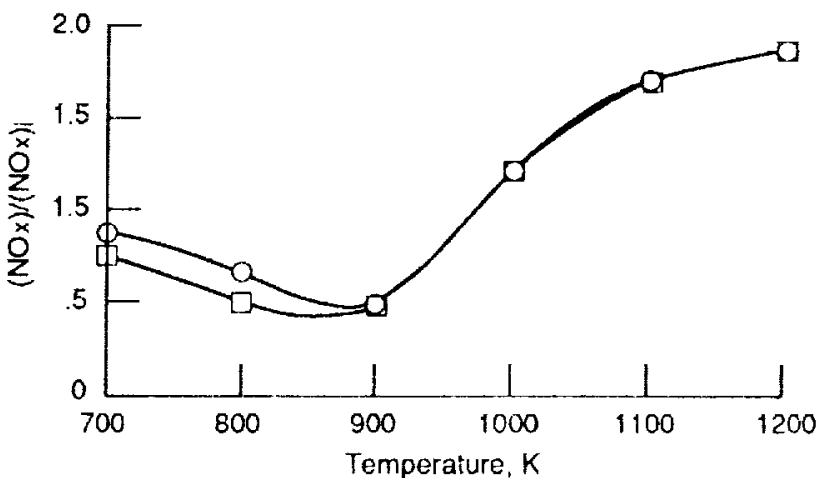

(b) The effect of ammonia on NOx in the presence of hydrocarbon fragment at various temperatures; 436 ppm $\mathrm{NO}$ and $463 \mathrm{ppm} \mathrm{NH}_{3}$.

Figure 7.--Effect of temperature on NO reduction in presence of $\mathrm{NH}_{3}$ 


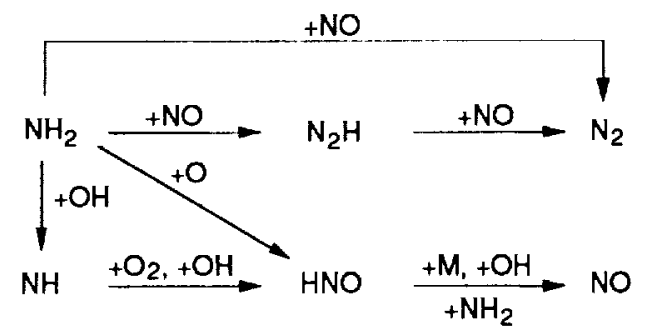

(a) Reduction path diagram.

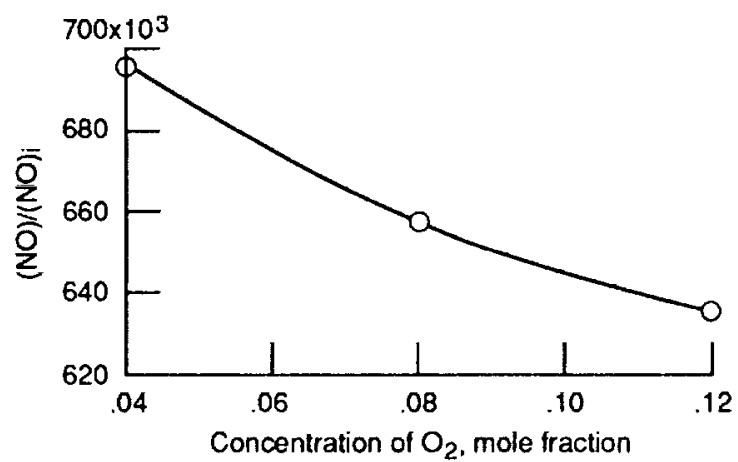

(b) Effect of oxygen concentration on reduction of NO by ammonia. Temperature, $1100 \mathrm{~K}$; 500 ppm NO; 300 msec.

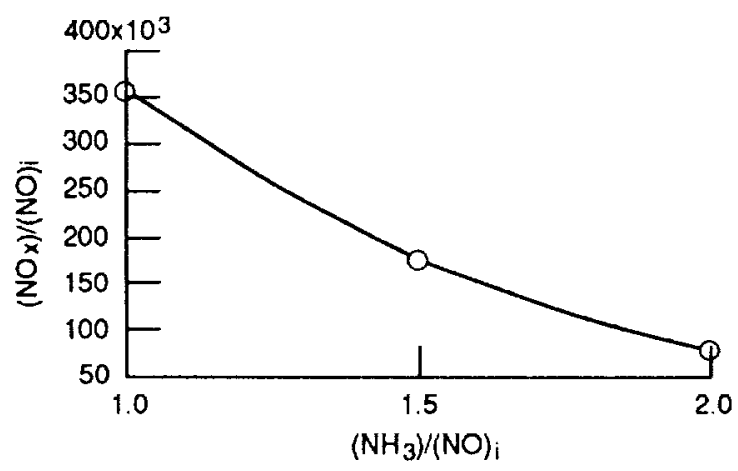

(c) Effect of ammonia and NO concentrations on NOx. Temperature, $1150 \mathrm{~K} ; 500 \mathrm{ppm}$ NO $300 \mathrm{msec}$

Figure 8.-Reduction of NO in presence of $\mathrm{NH}_{3}$

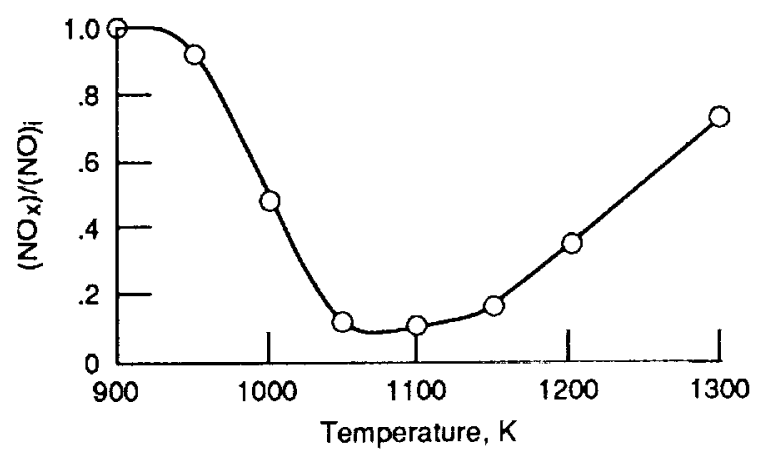

(a) 500 ppm NO, 500 ppm $\mathrm{NH}_{3}$, and $500 \mathrm{ppm} \mathrm{H}_{2}$

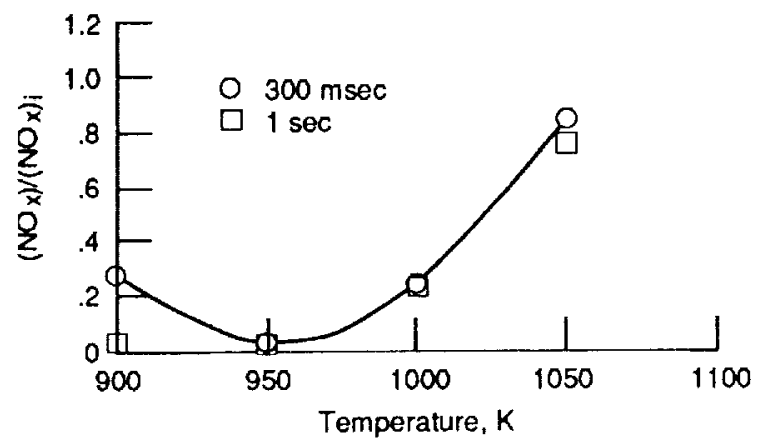

(b) $500 \mathrm{ppm} \mathrm{NO}, 500 \mathrm{ppm} \mathrm{NH}_{3}$, and $500 \mathrm{ppm} \mathrm{H}_{2}$.

Figure 9.-Effect of hydrogen on the reduction of $\mathrm{NO}$ by $\mathrm{NH}_{3}$. 


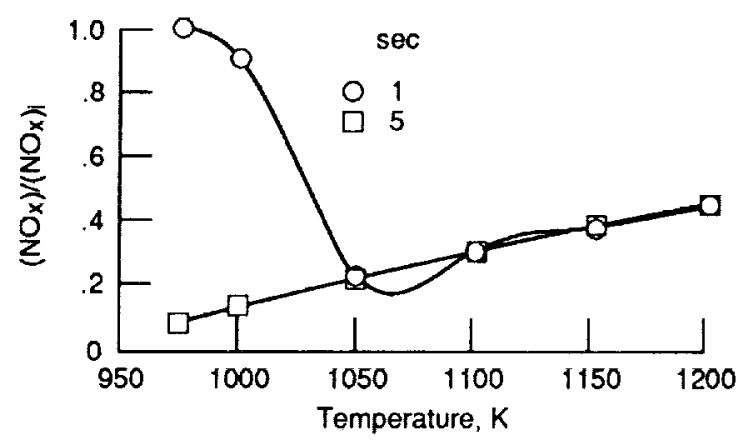

(a) Effect of ammonia on $\mathrm{NO}_{x}$ in presence of methanol; $500 \mathrm{ppm} \mathrm{NO}, 800 \mathrm{ppm} \mathrm{NH}_{3}$, and $500 \mathrm{ppm}$ methanol.

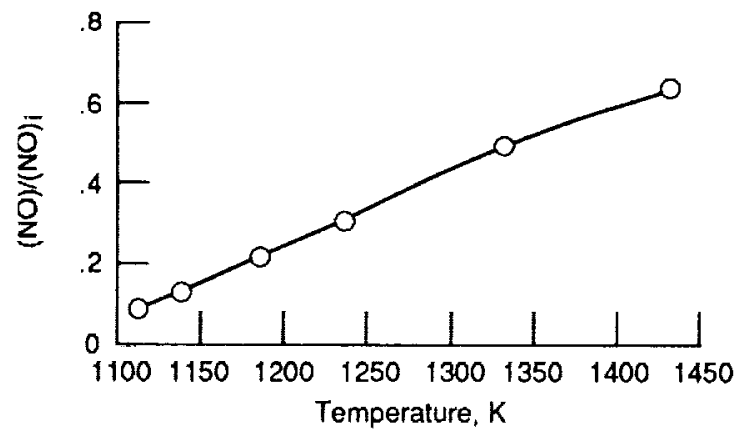

(b) Effect of reaction temperature on reduction of NO by the addition of ammonia; $500 \mathrm{ppm}$ $\mathrm{NO}, 750 \mathrm{ppm} \mathrm{NH}$, and $500 \mathrm{ppm}$ methanol. Time, $5 \mathrm{sec}$

Figure 10.-Effect of methanol on the reduction of $\mathrm{NO}$ in presence of $\mathrm{NH}_{3}$

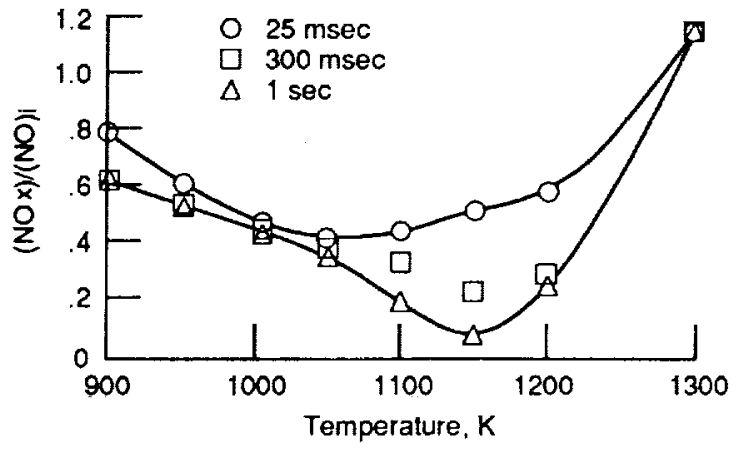

Figure 11.-Effect of $\mathrm{H}_{2} \mathrm{O}_{2}$ on $\mathrm{NO} \times$ reduction by ammonia; $500 \mathrm{ppm} \mathrm{NH}_{3}, 500 \mathrm{ppm} \mathrm{NO}$ and $500 \mathrm{ppm} \mathrm{H}_{2} \mathrm{O}_{2}$.

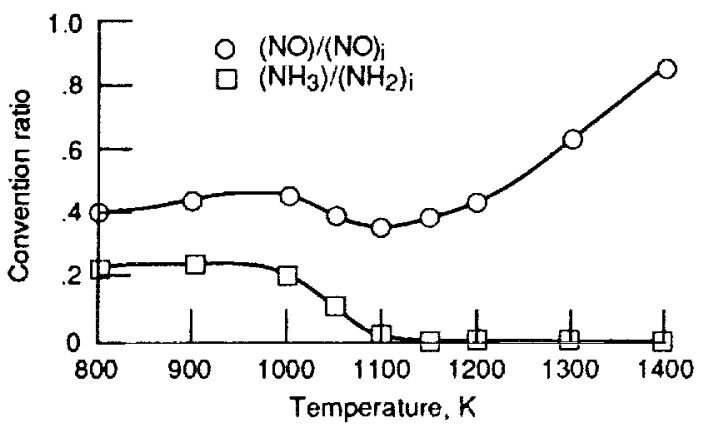

Figure 12.-Effect of temperature on NO reduction in the presence of $\mathrm{NH}_{2}$. 



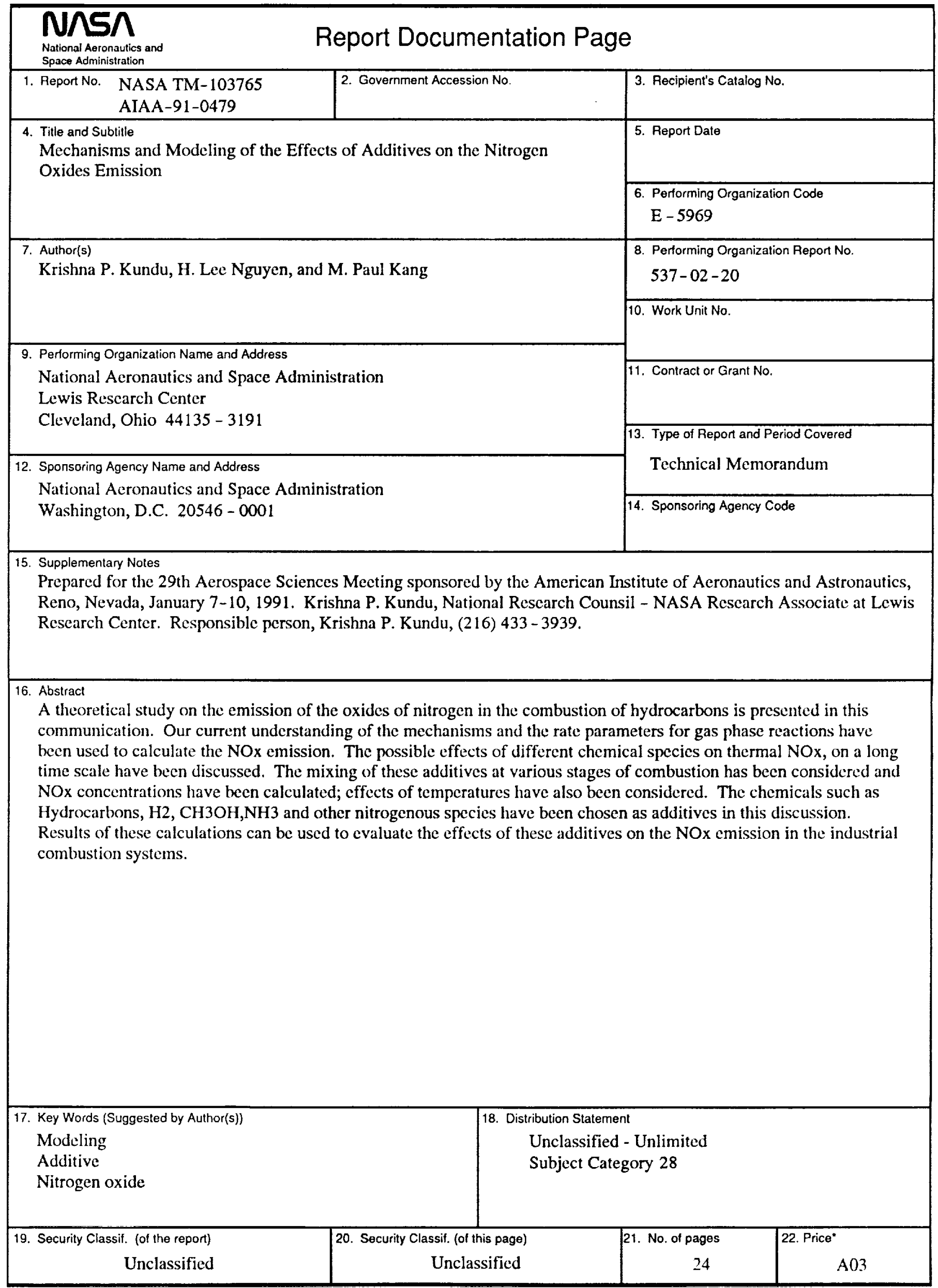

